\title{
Malatya Arkeoloji ve Etnoğrafya Müzelerinde Bulunan Türk- İslam Dönemi Mezar Taşları
}

\section{Turkish-Islamic Period Tombstones in Malatya Archeology and Ethnography Museums}

\author{
Sahure Yariş ${ }^{1}$ (D)
}

'Sorumlu yazar/Corresponding author:

Sahure Yariş (Dr. Öğr. Üyesi),

Dicle Üniversitesi, Edebiyat Fakültesi, Sanat Tarihi

Bölümü, Diyarbakır, Türkiye

E-posta: cinarsahure@gmail.com

ORCID: 0000-0002-1789-7470

Başvuru/Submitted: 25.11.2019

Revizyon Talebi/Revision Requested:

06.05.2020

Son Revizyon/Last Revision Received:

10.05.2020

Kabul/Accepted: 12.05 .2020

Online Yayın/Published Online: 30.06 .2020

Atıf/Citation: Yaris, Sahure, "Malatya Arkeoloji ve Etnoğrafya Müzelerinde Bulunan Türk- İslam Dönemi Mezar Taşları". Sanat Tarihi Yıllı̆̆ı -

Journal of Art History 29 (2020), 307-369. https://doi.org/10.26650/sty.2020.013

\section{öz}

Mezar taşları, kentlerin gelişim sürecinde en çok zarar gören eserlerin başında yer almaktadır. Bu eserler zamanla ya kaybolup gitmekte ya da ilgisizlik nedeniyle tahrip olmaktadır. Çalışmada; Malatya Arkeoloji ve Etnoğrafya Müzeleri'nde bulunan toplam 39 adet mezar taşı, sanat tarihi açısından belgelenerek değerlendirilmiştir. Kronolojik olarak tanıtılan taşlar, form bakımından kare ve dikdörtgen kesitli olarak iki ana gruba ayrılmaktadır. Süsleme programları ayrıntılı olarak ele alınmıştır. Motifler tanıtıııken önce motifin ikonografik gelişimi üzerinde durulmuştur. Estetik görünümleri ile mezarda yatanın kimliğini, sülâlesini, mesleğini unvanını, kullanılan isimleri, lakapları, ölüm sebeplerini, hastalıkları, yaratandan ve insanlardan istenilen isteklerini anlatması ve inanışlarla ilgili önemli bilgilerin yer aldığı bu eserler, ayrı ayrı ele alınıp genel bir değerlendirme yapılmıştır. Türk - İslam sanatı içerisindeki yeri üzerine durulmuş olan mezar taşlarının müzelere nereden getirildiği belirtilmiştir. Bu eserler; kültürel, sanatsal çeşitliliği bakımından hem yapıldıkları dönem içerisinde hem de bulundukları bölgenin aidiyetini temsil etmesi açısından son derece önemli eserlerdir.

Anahtar kelimeler: Malatya, Müze, Mezar taşı, Form, Süsleme

\section{ABSTRACT}

Tombstones are at the top of the most damaged works in the development process of cities. These works either disappear over time or are fallen into ruins due to indifference. In this study; a total of 39 tombstones in the Malatya Archeology and Ethnography Museums were evaluated by documenting with regards to art history. The stones, chronologically introduced, are divided into two main groups in terms of form as square and rectangular sectioned. Decoration programs were reviewed in detail. During the introduction of the motifs, the iconographic development of the motif was primarily emphasized. These works, with their aesthetic appearances, involving the deceased's identification, family, occupation, title, names, nicknames, causes of death, diseases, wishes from the Almighty, requests from the people, and significant information on beliefs, were reviewed individually and a general evaluation was conducted. The study states where the tombstones, whose place in Turkish-Islamic art was emphasized, were brought from to the museums. These works are crucial in terms of cultural and artistic diversity both in the period of their production and also by means of representing the regional belonging.

Keywords: Malatya, Museum, Tombstone, Form, Decoration 


\section{Giriş}

Ölüm, tüm canlılar için kaçınılmazdır. Ölümün varlığını bilmek, insanın hem yaşamına kutsal bir anlam katmada yardımcı olur hem de öldükten sonra bedenin ve ruhun ne olacağ konusunda kutsal anlamlar yüklemede kaynaklık eder. Bu inançların şekillenmesinde kültürlerin uygarlık düzeyi, gelenekler ve dinleri, birbirleriyle olan ilişkileri önemli rol oynamıştır.

Ölen kişinin arkasından çeşitli ritüeller yapılmaktadır. Yapılan ritüellerin amaçlarından biri, ölen kişiye saygı duymak, bir diğeri ise insanın ölüm karşısında yaşadığı üzüntüyü ve duyduğu korkuyu anlatmaktır. Uygulanan ritüellerden biri ölü gömme adetleridir. Bu adetin yanı sıra Orta Asya' da uygulanan çeşitli ritüeller vardır. Bunlar; toprağa gömme, yakma, doğaya terketme ve mumyalamadır ${ }^{1}$. Bu çeşitlilik arasında en çok uygulanan ritüel mezara gömmedir.

Ölen insanlar için mezarlar açmak, o mezarların üzerine taş dikmek binlerce yıldır süregelen bir gelenektir. Ölen kişinin unutulmaması, mezarın kime ait olduğunun belirtilmesi için en ilkel toplumlardan en gelişmiş toplumlara kadar mezar taşı dikme inancı devam etmiştir. Orta Asya'dan itibaren devam eden bu gelenekle taşlar, hem belirli bir olgunluğa ulaşmış hem de estetik değeri yüksek eserler haline gelmiştir².

Türkler, çok farklı coğrafyalarda yaşamıştır. Yaşadığg farklı coğrafyalarda, farklı toplumlarla hem sosyal hem dini etkileşimlerde bulunmuşlardır. Bu farklılıklar, çeşitli ölüm ritüelleri benimsemelerine, zengin bir mezar ve mezar taşı kültürlerine sahip olmalarına sebep olmuştur. Kurgan, balbal, kümbet gibi mezar yapıları bu çeşitliliğin ve zenginliğin ürünlerindendir. Mezar taşları ölenlerin geçmişten geleceğe mesajlarını ileten en önemli iletişim araçları içinde yer almışlardır ${ }^{3}$. Aynı zamanda bu taşlar, ait oldukları medeniyetin sanat, kültür ve sosyal durumunu en iyi şeklide ortaya koyan eserlerdir.

Türklerde mezar taşı geleneği, coğrafi bölge ve inanç sistemindeki değişikliklerle Orta Asya'dan günümüze kadar varlığını sürdürmüştür. İlk dönemlerde süslemesiz ve yüksek taşlar mezarın yerini belirlemek için kullanılırken, zamanla taşlar, üzerine yapılan süslemelerle gelişmelerini sürdürmüştür. Türk Kültür coğrafyasında Göktürk balbalları şeklinde ortaya çıkan, insanı anımsatan heykelimsi bir görünüme sahip olan bu eserler; Selçuklular döneminde sandukalı ve şahideli görünüm kazanmıştır. Gelenek ve inançların etkisiyle taşlar üzerinde süslemeler yapılmış, yazı eskiye oranla daha fazla kullanılmıştır. Osmanlının ilk zamanlarında bitkisel, hayvansal ve figüratif bezemeli mezar taşları görülürken, klasik döneme gelindiğinde mezar taşları yalın bir görünüme sahiptir. Bu yalınlık Lale devrinde çiçek motifleriyle bozulmuştur. Taşlar üzerindeki süslemeler, XVIII. yüzyılın ikinci yarısından itibaren dış etkilerle birlikte

1 Jean- Louis Bacque, “Osmanlı Mezarlıklarının İncelenmesi: Yöntemler ve Geleceğe Dönük Düşünceler”, İslam Dünyasında Mezarlıklar ve Defin Gelenekleri I, Ankara, 1996, s. 138-140.; Halit Çal, "Malatya Kırklar Mezarlığındaki Mezar- Mezar Taşı Tipleri”, Milli Folklor Dergisi, S. 115, 2017, s. 63-78.; Ertan Daş, İzmir'de Taş Çiçekler, İzmir Büyükşehir Belediyesi Kent Kitaplığı, İzmir, 2012, s. 11.

2 Zafer Ertaş, "Antalya Bölgesi Bir Grup Mezar Taşı Üzerindeki Yorumlar”, Sanat Tarihi Yıllığı, S.12, İstanbul, 1983, s. 23.

3 Gülay Apa Kurtişoğlu, "Sadelikten Gösterişe Edirne Osmanlı Dönemi Mezar Taşları”, Trakya Üniversitesi Edebiyat Fakültesi Dergisi, C.8, S. 16, Edirne, 2018, s. 34. 
yalın ve dinginliğini kaybedip daha süslü ifadelere bürünmüşlerdir ${ }^{4}$. Türk plastik sanatları bakımından önemli eserler haline gelmişlerdir.

Çalışma konumuz olan mezar taşları Malatya Arkeoloji ve Etnoğrafya Müzeleri'nde koleksiyonlarda yer almakta olup bunlar; Malatya'nın Battalgazi İlçesi Kırklar Mezarlığı'ndan, bir okul deposundan ve satın alma yoluyla oluşturulmuştur. Makalemizde kendi dönemlerinin beğenileriyle süslü, değişik kompozisyonlarla bezeli 39 mezar taşı incelenmiştir.

\section{Katalog}

Katalog No: 1

Bulunduğu Müze: Arkeoloji Müzesi

Müzeye Getirildiği Yer: Kırklar Mezarlığı

Ölçüleri (cm.): En: 25 Boy: 31 Kalınlık: 6,5

İşleniş Tekniği: Kabartma

Kitabesi:

\begin{tabular}{|c|c|}
\hline $\begin{array}{c}\text { Cemadiye'l-Ahir } \\
\text { Sene seb'a ve seb'a mie }\end{array}$ & r- إنة سبع وسبعمائة \\
\hline
\end{tabular}

Anlamı: Cemaziyülahır (ayında) Yedi yüz yedi yılında (Miladi Kasım/Aralık 1307)

Tanım ve Kompozisyon: Üst ve alt kısımlardan krırık olan taş, dikdörtgen kesitli ve düşey dikdörtgen gövdeye sahiptir. Taşın ön yüzeyinde kabartma tekniğinde yazılmış, ortada bir kartuşla ayrılan iki satır kitabe kalmıştır (F.1). Gövdesinin büyük kısmı kırık olan taşın arka yüzeyinde çift zincirle asılı duran bir kandil motifi olduğu anlaşılmaktadır. Dışta taşın alt kısmından yukarıya doğru daralan zincir, iç kısımdaki daha dar olan diğer zincirle üst bölümde birer küçük dairesel düğümlerle birbirine bağlanmıştır. Kandilin hemen üst kısmında ise bir palmet motifi işlenmiştir. Palmet, üzerinde oval formda boğumları olan zincirle kandilin diğer zincirlerine birleştirilmiştir (F.2a, F.2b).

4 Metin Haseki, Plastik Açıdan Türk Mezar Taşları, İstanbul, Devlet Güzel Sanatlar Akademisi Yayınları, 1984, s.10.; H. Kamil Biçici, “Tire Müzesi’nde Bulunan Süslemeli Mezar Taşlarından Bazı Örnekler (XVIII-XX. yy.)”, Ankara Üniversitesi İlahiyat Fakültesi Dergisi, S.50, Ankara, 2009, s. 110-111. 


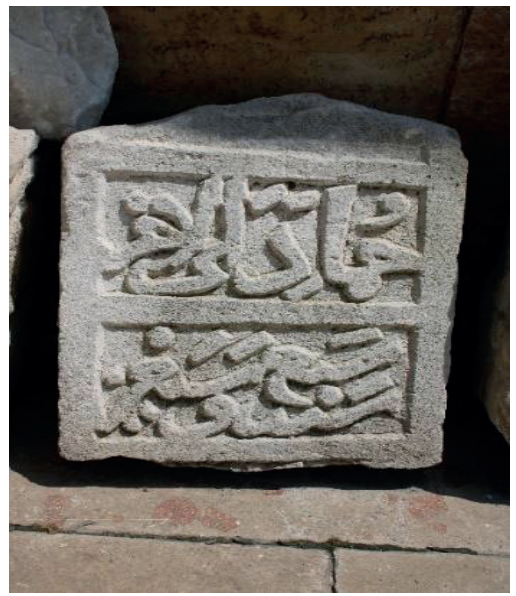

F. 1: Katalog No 1

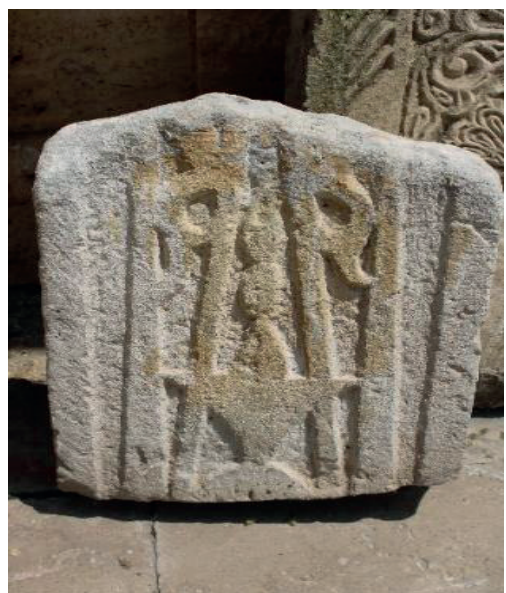

F. 2a: Katalog No 1

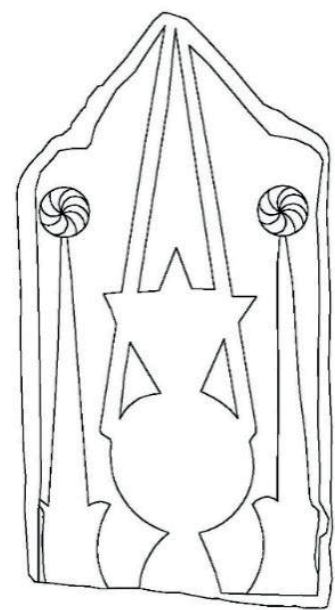

F. 2b: Katalog No 1

Katalog No: 2

Bulunduğu Müze: Arkeoloji Müzesi

Müzeye Getirildiği Yer: Okul deposu

Ölçüleri (cm.): En: 37 Boy: 50 Kalınlık: 10

İşleniş Tekniği: Kabartma

Kitabesi: 


\begin{tabular}{|c|c|}
\hline $\begin{array}{l}\text { İntikalu ila rahmetu'l-Lahi Teâlâ } \\
\text { Fi samin 'aşere Safer'u'l-Mubarek } \\
\text { Sene seman ve erba'in ve seb'a mie }\end{array}$ & 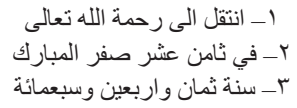 \\
\hline
\end{tabular}

Anlamı: Mübarek Safer ayının on sekizinde yedi yüz kırk sekiz (30 Mayıs Çarşamba 1347) yılında şanı yüce her şeye gücü yeten Allah'ın rahmetine intikal etti.

Tanım ve Kompozisyon: Dikdörtgen kesitli, düşey dikdörtgen gövdeye sahip olan taşın üst kısmı pahlanarak tamamlanmıştır. Taşın yüzeyinde kabartma tekniğinde yazılmış üç satırlık kitabe yer alır. Kitabe satırları birbirinden kartuşlarla ayrılmıştır. Kitabe dıştan etrafı geometrik şekiller olan baklava dilimlerinin dizilmesiyle oluşturulmuş bir bordürle sınırlandırılmıştır. Taşın her iki kenarında ise iç içe geçmiş zincir motifleri işlenmiştir (F.3a, F.3b).

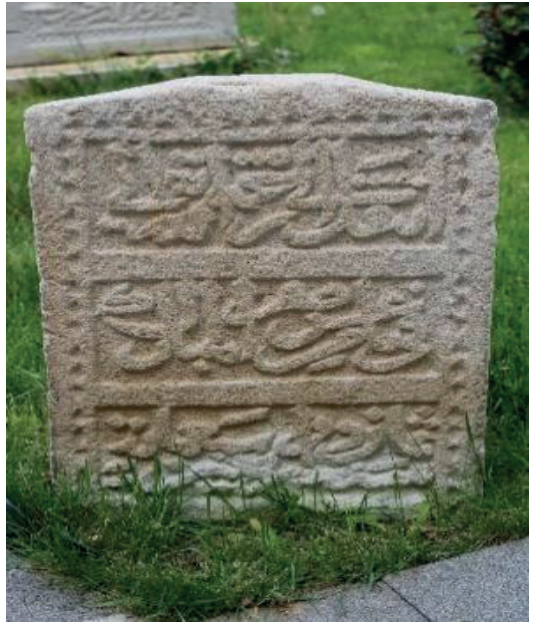

F. 3a: Katalog № 2

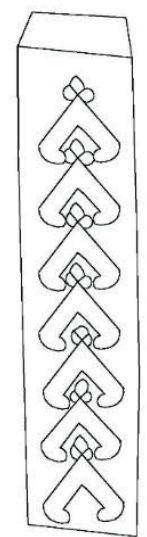

F. 3b: Katalog № 2

Katalog No: 3

Bulunduğu Müze: Etnoğrafya Müzesi

Müzeye Getirildiği Yer: Kırklar Mezarlığı

Ölçüleri (cm.): En: 15 Boy: 50 Kalınlık: 7

İşleniş Tekniği: Kabartma

Kitabesi: 


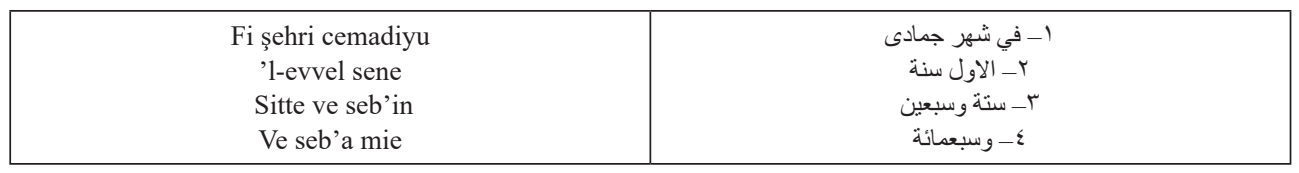

Anlamı: Cemaziyülevvel ayında yedi yüz yetmiş altı (miladi Ekim-Kasım 1374) yılında (vefat etti)

Tanım ve Kompozisyon: Dikdörtgen kesitli, düşey dikdörtgen gövdeye sahip olan taşın ön yüzeyinde dört satırlık kitabe metni yer alır. Birbirlerinden kartuşlarla ayrılan kitabe satırları kabartma tekniğinde işlenmiştir (F.4). Taşın arka yüzeyinde süsleme vardır. Ortada bir kandil ve kandilin her iki yanında birer şamdan motifi işlenmiştir. Kandilin her iki yanında yer alan, kandili asmak için kullanılan birer ip görünümlü zincir yer alır. Bu zincirlerin orta kısmında kandilin genişleyen ağız kısmı ve dışarıya doğru verilmiş fitili işlenmiştir. Fitilin üst kısmında her iki yana doğru önce açılıp sonra yukarıya doğru kıvrım yapan birer palmet motifi yer alır. Kandili asmak için düzenlenmiş zincirlerin üst kısımda birleşme noktalarında dört kenara doğru açılan yapraklar işlenmiştir. Kandilin her iki yanında birer şamdan bulunmaktadır. Süsleme kompozisyonu üst kısımda dilimli sivri kemerle sonlandırılmıştır (F.5a, F.5b).

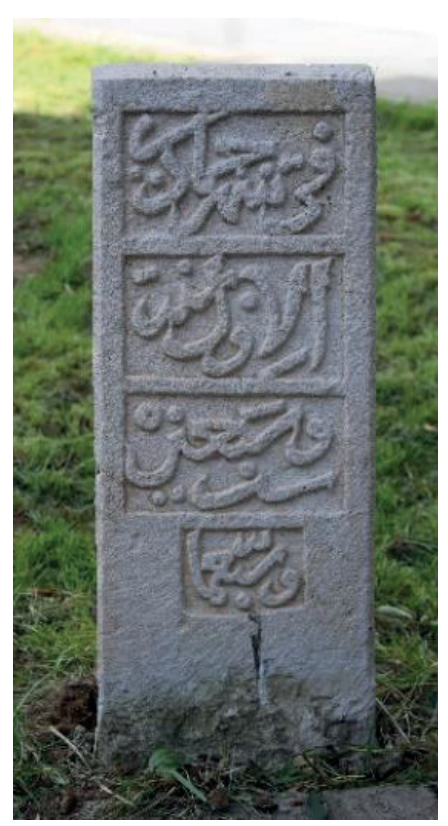

F. 4: Katalog No 3 


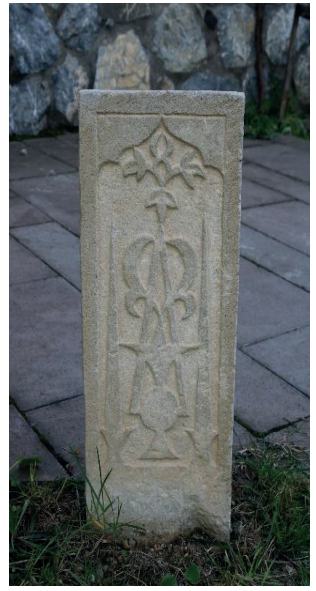

F. 5a: Katalog No 3

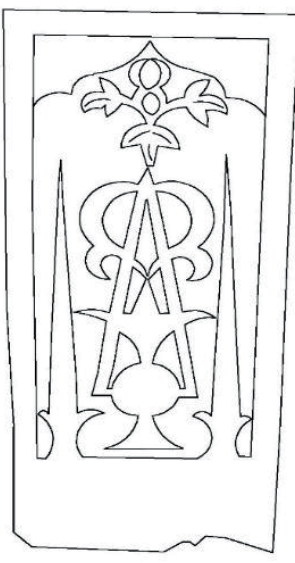

F. 5b: Katalog No 3

Katalog No: 4

Bulunduğu Müze: Arkeoloji Müzesi

Müzeye Getirildiği Yer: Okul deposu

Ölçüleri (cm.): En: 45,5 Boy: 52 Kalınlık: 9

İşleniş Tekniği: Kabartma

Kitabesi:

\begin{tabular}{|c|c|}
\hline $\begin{array}{c}\text { Haza kabru'l-merhum... } \\
\text { Fi saniyi Cemadiyu'l-Ahire } \\
\text { Sene hamse ve selasin ve seman mie }\end{array}$ & 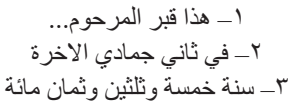 \\
\hline
\end{tabular}

Anlamı: Bu kabir merhum... Cemziyelahır ayının ikisinde sekiz yüz otuz beş (miladi 5 Şubat Salı 1432) yılında

Tanım ve Kompozisyon: Dikdörtgen kesitli ve düşey dikdörtgen gövdeye sahip olan taşın alt kısmı kırıktır. Taşın yüzeyinde üç satırlık kitabe metni yer almaktadır. Kabartma tekniğiyle işlenmiş olan kitabe satırları birbirinden düz kartuşlarla ayrılmıştır (F.6). 


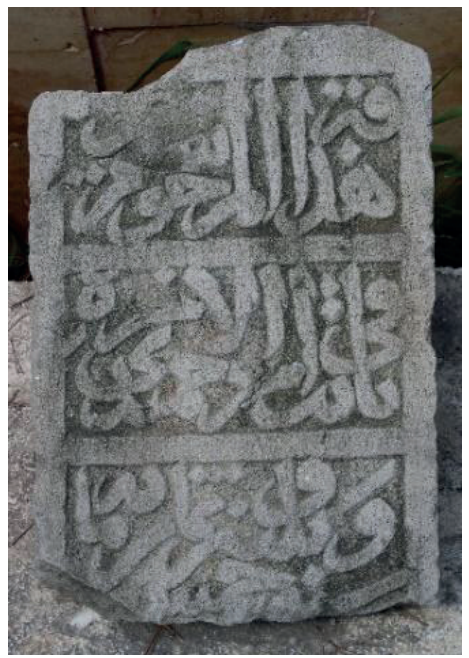

F. 6: Katalog No 4

Katalog No: 5

Bulunduğu Müze: Etnoğrafya Müzesi

Müzeye Getirildiği Yer: Satın alma

Ölçüleri (cm.): En: 15,5 Boy: 30 Kalınlık: 8,5

İşleniş Tekniği: Kabartma

Kitabesi:

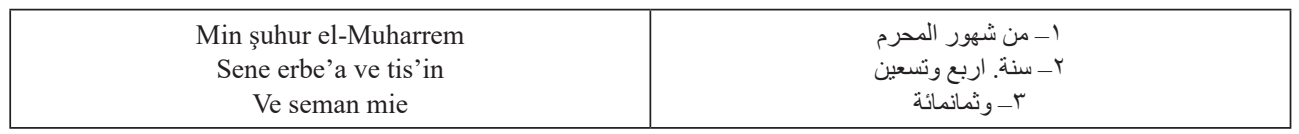

Anlamı: Muharrem ayında sekiz yüz doksan dört (miladi Aralık 1488 - Ocak 1489) yılında (vefat etti)

Tanım ve Kompozisyon: Taş, dikdörtgen kesitli, düşey dikdörtgen gövdeye sahiptir. Yüzeyinde üç satırlık kitabe metni yer alır. Kabartma tekniğiyle işlenmiş olan kitabe satırları birbirinden geniş kartuşlarla ayrılmıştır (F.7). 


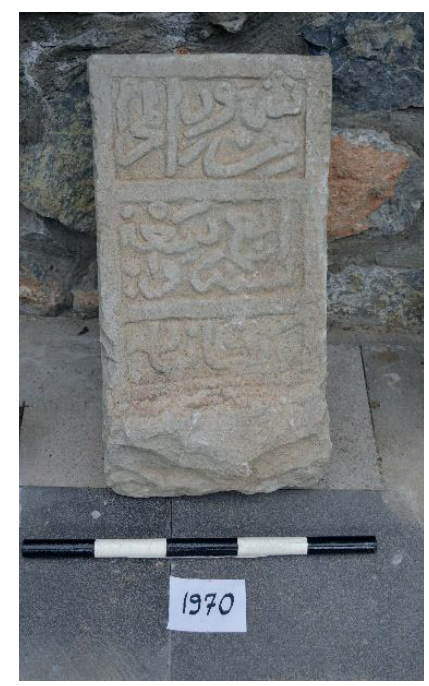

F. 7: Katalog No 5

Katalog No: 6

Bulunduğu Müze: Etnoğrafya Müzesi

Müzeye Getirildiği Yer: Satın alma

Ölçüleri (cm.): En: 20 Boy: 65 Kalınlık: 9

İşleniş Tekniği: Kabartma

Kitabesi:

\begin{tabular}{|c|c|}
\hline $\begin{array}{c}\text { Ya Ğaffar } \\
\text { Haza'l-merhume } \\
\text { 'l-mağfure... } \\
\text {... binti Sami? } \\
\text { Ruhiçün } \\
\text { el-Fatiha } \\
\text { Sene 1113? (hicri) }\end{array}$ & 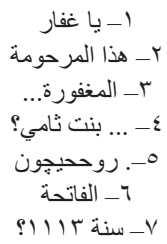 \\
\hline
\end{tabular}

Anlamı: Ey bağışlaması bol olan Gaffar! Bu merhume ve mağfure, Sami kızı... ruhuna el-Fatiha sene 1701

Tanım ve Kompozisyon: Dikdörtgen kesitli, düşey dikdörtgen gövdeye sahip olan taş, üçgen alınlık formunda tamamlanmıştır. Eserin alınlık kısmını oluşturan üçgen kısım taşın kenarlarından dışa doğru taşırılmıştır. Taşın yüzeyinde yedi satırlık kitabe metni yer alır. Kabartma tekniğinde işlenmiş olan kitabe üçgen alınlık kısmından başlamaktadır ve kitabeyi oluşturan satırlar arasında kartuşa yer verilmemiştir (F.8). 


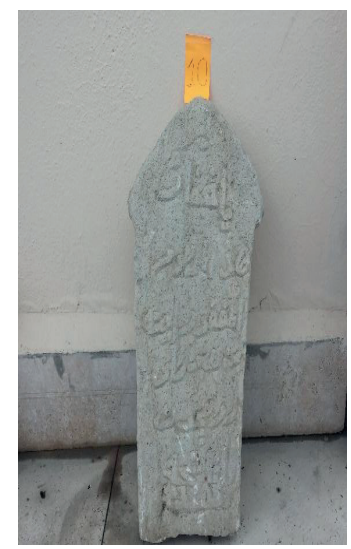

F. 8: Katalog No 6

Katalog No: 7

Bulunduğu Müze: Etnoğrafya Müzesi

Müzeye Getirildiği Yer: Satın alma

Ölçüleri (cm.): En: 18 Boy: 52 Kalınlık: 18

İşleniş Tekniği: Kabartma

Kitabesi:

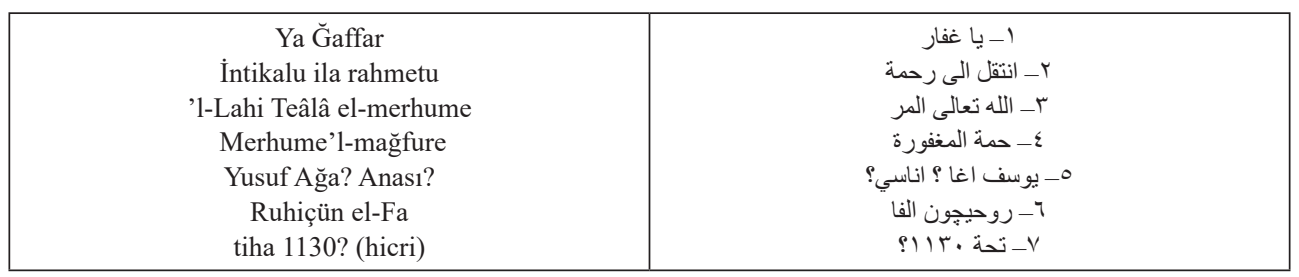

Anlamı: Ey bağışlaması bol olan Gaffar! Şanı yüce her şeye gücü yeten Allah'ın rahmetine intikal eden merhume, mağfure Yusuf Ağa'nın annesinin ruhu için el-Fatiha 1718 (miladi)

Tanım ve Kompozisyon: Kareye yakın prizmal kesitli ve düşey dikdörtgen gövdeye sahip olan taş, başlıklıdır. Kalpak ${ }^{5}$ adı verilen bir başlıkla sonlandırılmış olan taşın yüzeyinde yedi satırlık kitabe metni yer alır. Kabartma tekniğinde işlenmiş olan kitabe satırları arasında kartuş kullanılmamıştır (F.9).

5 H. Necdet İşli, Osmanlı Serpuşları, İstanbul, Avrupa Kültür Başkenti, Ebru Maatbacılık, 2009, s. 138. 


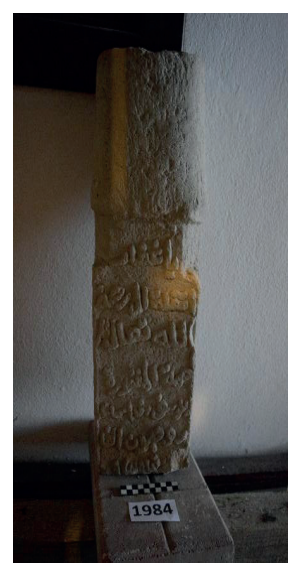

F. 9: Katalog No 7

Katalog No: 8

Bulunduğu Müze: Arkeoloji Müzesi

Müzeye Getirildiği Yer: Okul deposu

Ölçüleri (cm.): En: 16,5 Boy: 45 Kalınlık: 16,5

İşleniş Tekniği: Kabartma

Kitabesi:

\begin{tabular}{|c|c|}
\hline $\begin{array}{l}\text { İntikalu ila rahmetu } \\
\text { '1-Lahi teala el-merhumetu } \\
\text { '1-mağfure Amine? } \\
\text { Binti Mümezruc? } \\
\text { İçün Fatiha } \\
\text { Sene } 1160 \text { (hicri) }\end{array}$ & 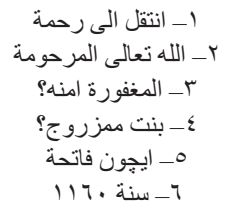 \\
\hline
\end{tabular}

Anlamı: Şanı yüce her şeye gücü yeten Allah'ın rahmetine intikal etmiş olan merhum ve mağfur Mümezruc? Kızı Amine? İçin fatiha. Sene 1747 (miladi)

Tanım ve Kompozisyon: Kareye yakın prizmal kesitli ve düşey dikdörtgen gövdeye sahip olan taşın üst kısmı kırıktır. Taşın yüzeyinde altı satırlık kitabe yer almaktadır. Kabartma tekniğiyle işlenmiş olan kitabe satırları kartuşlarla birbirinden ayrılmamıştır (F.10). 


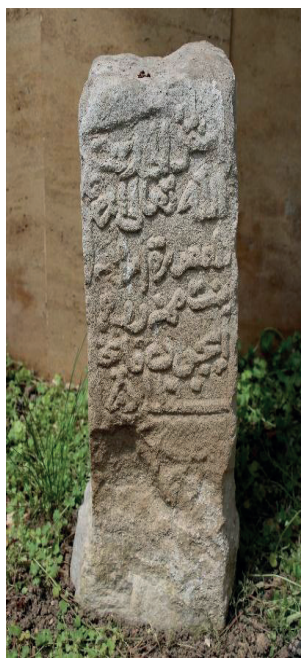

F. 10: Katalog № 8

Katalog No: 9

Bulunduğu Müze: Arkeoloji Müzesi

Müzeye Getirildiği Yer: Okul deposu

Ölçüleri (cm.): En: 17 Boy: 90 Kalınlık: 17

İşleniş Tekniği: Kabartma

Kitabesi:

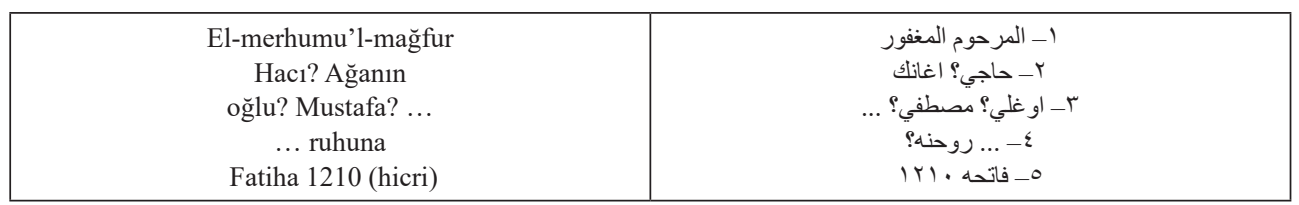

Anlamı: Merhum ve mağfur Hacı Ağanın oğlu Mustafa ruhuna Fatiha 1792 (miladi)

Tanım ve Kompozisyon: Kareye yakın prizmal kesitli ve düşey dikdörtgen gövdeye sahip olan taş başlıklı olarak yapılmıştır. Dolama ${ }^{6}$ diyebileceğimiz bu başlık kavuk etrafına kıvrılmış bezin sarılması suretiyle meydana getirilmiştir. Taşın yüzeyinde kabartma tekniğinde işlenmiş beş satırlık kitabe yer almaktadır. Kitabe satırları arasında kartuş kullanılmamıştır (F.11).

6 İşli, a.g.e., s. 33. 


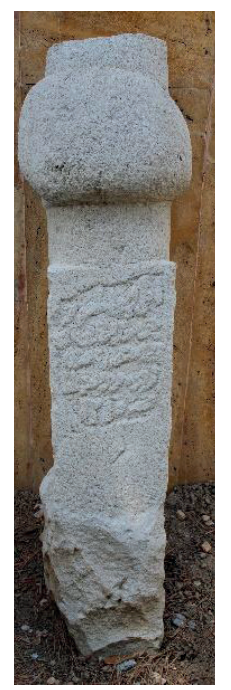

F. 11: Katalog No 9

Katalog No: 10

Bulunduğu Müze: Arkeoloji Müzesi

Müzeye Getirildiği Yer: Okul deposu

Ölçüleri (cm.): En: 14,5 Boy: 62 Kalınlık: 14,5

İşleniş Tekniği: Kabartma

Kitabesi:

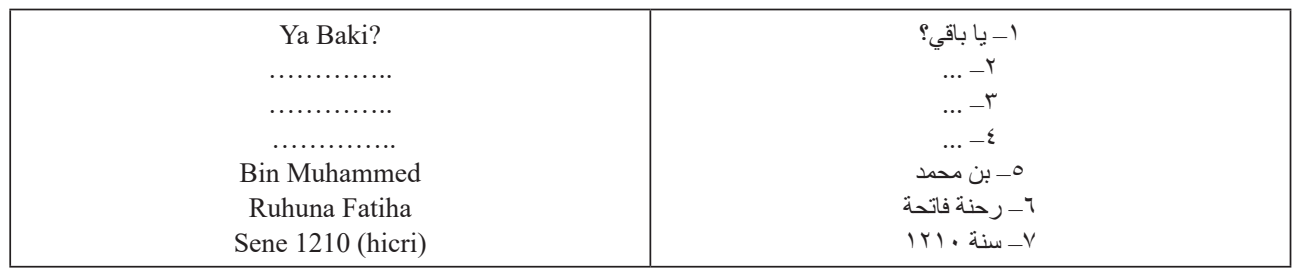

Anlamı: Ey Daim olan! Muhammed oğlu... ruhuna Fatiha sene 1795 (miladi)

Tanım ve Kompozisyon: Kareye yakın prizmal kesitli ve düşey dikdörtgen gövdeye sahip olan taş, başlıklı olarak yapılmıştır. Kalpak ${ }^{7}$ adı verilen bir başlıkla tamamlanmış olan taşın yüzeyinde yedi satırlık kitabe metni yer almaktadır. Kabartma tekniğinde işlenmiş olan kitabe satırları arasında kartuş bulunmamaktadır (F.12).

7 Kalpak: Yeniçeri teşkilatı dâhilinde Topçu ve Cebeciler arasında bir zümre olan Humbaracıların kullandığı başlık türlerinden biridir. Kaynaklarda "Şubara" olarak geçen bu başlık yuvarlak, boru gibi uzun idi. Humbaracıların derecelerine göre kırmızı, beyaz ve keçe renginde olurdu. Alt kısmı ve üst kısmı aynı çapta olup üst kısmı hafifçe içe çökük olurdu. İşli, a.g.e., s. 138. 


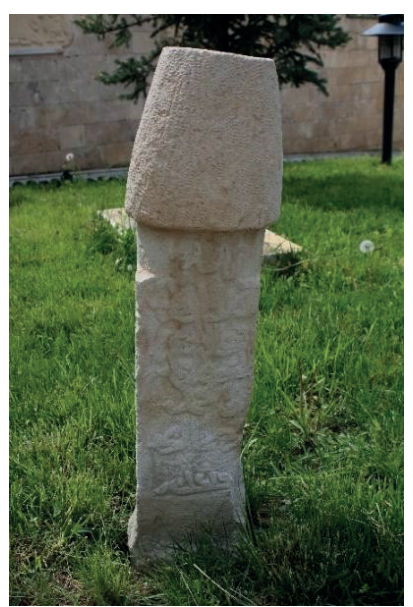

F. 12: Katalog No 10

Katalog No: 11

Bulunduğu Müze: Arkeoloji Müzesi

Müzeye Getirildiği Yer: Okul deposu

Ölçüleri (cm.): En: 26 Boy: 39 Kalınlık: 10

İşleniş Tekniği: Kabartma

Kitabesi:

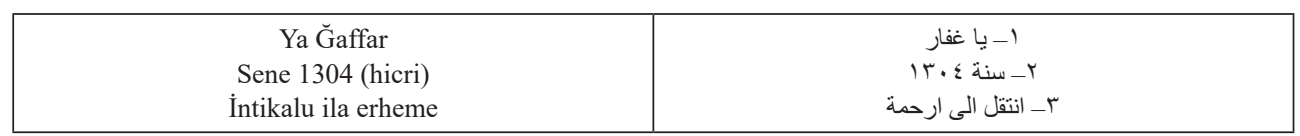

Anlamı: Ey mağfiret eden! Sene 1886 (miladi). Rahmete intikal eden

Tanım ve Kompozisyon: Üst kısımda yarım yuvarlak formda alınlıkla tamamlanmış olan taşın, alt kısımda kalan bölümünde dikdörtgen kesitli ve düşey dikdörtgen gövdeye sahip olduğu anlaşılmaktadır. Taşın yüzeyinde üç satırlık kitabe metni yer almaktadır. Kabartma tekniğinde işlenmiş olan kitabe satırları arasında kartuşa yer verilmemiştir. Kartuş, üst kısımda yarım yuvarlak olarak kitabenin çevresinde işlenmiş, kalan kısımlarda ise bu kartuşun taşın alt kısmına doğru devam ettiği anlaşılmaktadır. Kitabenin ilk iki satırı taşın alınlık kısmı olan yarım yuvarlak form içerisinde işlenmiştir. Kitabenin kalan son satırı ise dikdörtgen gövde de yer almaktadır (F.13). 


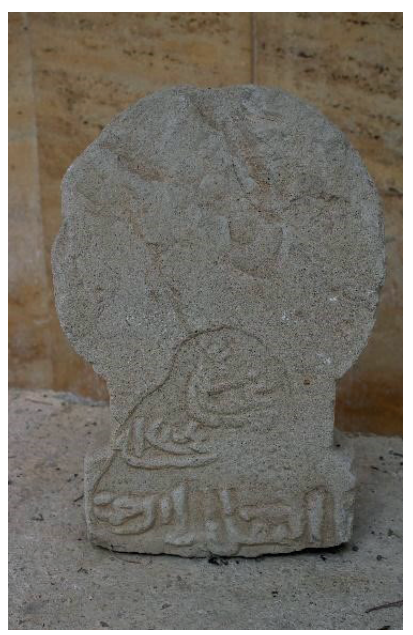

F. 13: Katalog No 11

Katalog No: 12

Bulunduğu Müze: Etnoğrafya Müzesi

Müzeye Getirildiği Yer: Satın alma

Ölçüleri (cm.): En: 17 Boy: 87 Kalınlık: 17

İşleniş Tekniği: Kabartma

Kitabesi:

\begin{tabular}{|c|c|}
\hline $\begin{array}{c}\text { Ya Ğaffar } \\
\text { İntikalu ila rahmetu'l-Lahi } \\
\text { Teâlâ el-merhumu'l-mağfur } \\
\text { Merhume'l-mağfure } \\
\text { Muhammed bin İsmail } \\
\text { Ruhiçün el-Fatiha } \\
\text { Sene } 1306 \text { (hicri) }\end{array}$ & 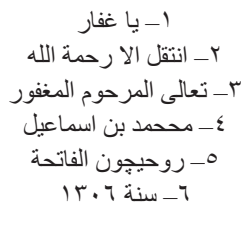 \\
\hline
\end{tabular}

Anlamı: Ey bağışlaması bol olan Gaffar! Şnı yüce her şeye gücü yeten Allah'ın rahmetine intikal eden merhum ve mağfur İsmail oğlu Muhammed'in ruhu için el-Fatiha sene 1888 (miladi)

Tanım ve Kompozisyon: Taş, kareye yakın prizmal kesitli ve düşey dikdörtgen gövdeye sahiptir. Kalpak ${ }^{8}$ adı verilen bir başlıkla tamamlanmıştır. Taşın yüzeyinde kabartma tekniğyle işlenmiş altı satırlık kitebe metni yer alır. Satırlar arasında kartuş yapılmamıştır. Kitabenin ilk satırı üst kısımda yarım yuvarlak bir kartuşla sınırlandırılmışıtır (F.14).

8 İşli, a.g.e., s. 138. 


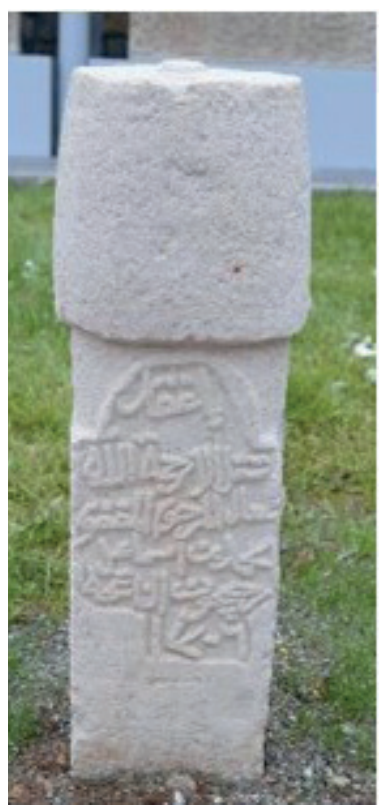

F. 14: Katalog No 12

Katalog No: 13

Bulunduğu Müze: Etnoğrafya Müzesi

Müzeye Getirildiği Yer: Satın alma

Ölçüleri (cm.): En: 18 Boy: 103 Kalınlık: 18

İşleniş Tekniği: Kabartma

Kitabesi:

\begin{tabular}{|c|c|}
\hline $\begin{array}{c}\text { Sene } 1315 \text { (hicri) } \\
\text { İntikalu ila rahmetu'l-Lahi } \\
\text { Teâlâ el-merhumu'l-mağfur } \\
\text { Hacı Hafız Muhammed } \\
\text { Bin Emir Hadi } \\
\text { Ruhuna el-Fatiha }\end{array}$ & 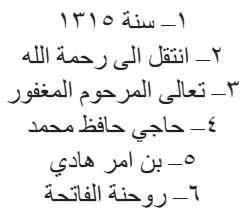 \\
\hline
\end{tabular}

Anlamı: Ey bağışlaması bol olan Gaffar! Şnı yüce her şeye gücü yeten Allah'ın rahmetine intikal eden merhum ve mağfur İsmail oğlu Muhammed'in ruhu için el-Fatiha sene 1897 (miladi)

Tanım ve Kompozisyon: Kareye yakın prizmal kesitli ve düşey dikdörtgen gövdeye sahip olan taş Çatal Kalafat ${ }^{9}$ başlıkla sonlandırılmıştır. Taşın yüzeyinde altı satırlık kitebe yer alır. Kabartma tekniğinde işlenen kitabe satırları arasında kartuşa yer verilmemiştir (F.15).

9 İşli, a.g.e., s. 128. 


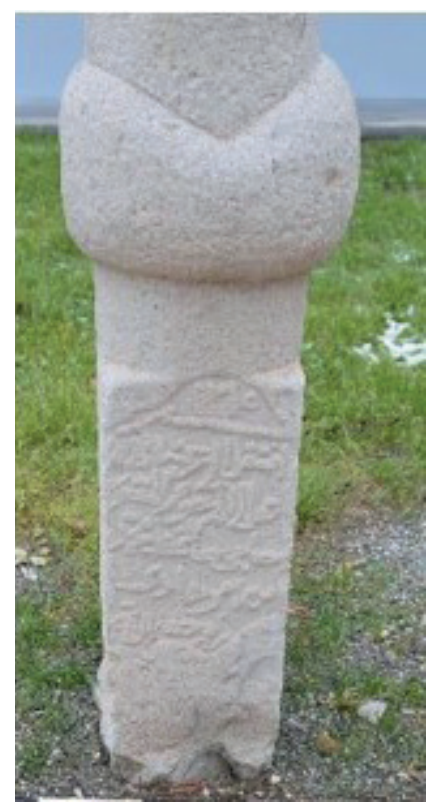

F. 15: Katalog No 13

Katalog No: 14

Bulunduğu Müze: Arkeoloji Müzesi

Müzeye Getirildiği Yer: Okul deposu

Ölçüleri (cm.): En: 15 Boy: 43 Kalınlık: 15

İşleniş Tekniği: Kabartma

Kitabesi:

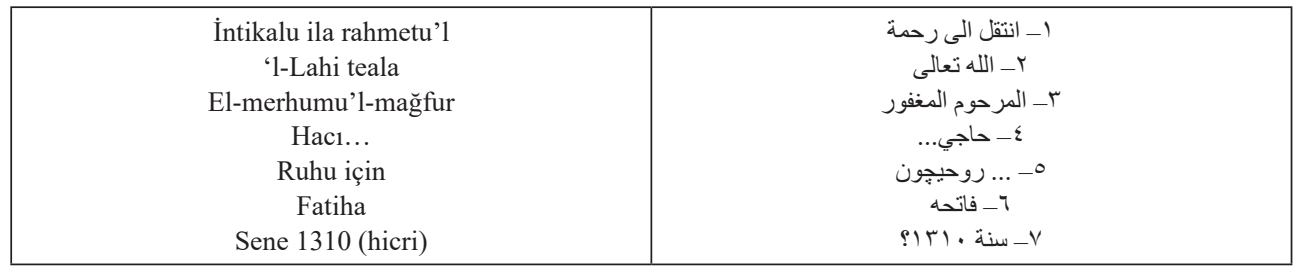

Anlamı: Allah'ın rahmetine intikal etti. Merhum ve mağfur Hacı... ruhu için Fatiha. Sene 1892 (miladi)

Tanım ve Kompozisyon: Kareye yakın prizmal kesitli ve düşey dikdörtgen gövdeye sahip olan taşın üst kısmı kırıktır. Taşın ön yüzeyinde kabartma tekniğinde yazılmış kitabe yer alır (F.16). Yüzeye düz bir şekilde yazılmış olan kitabe satırlarını ayırmak için kartuşa yer 
verilmemiştir. Taşın arka yüzünde süsleme uygulanmıştır. Taşın üst kısmında aşağıya doğru sarkan, sanki boyna asılmış gibi duramn bir hamâil (hamaylı) vardır. Üç üçgen şekilden oluşan hamâilin üst kısmında günlük hayatta kullanılan bir kepçe ve bir kaşığa yer verilmiştir (F.17).

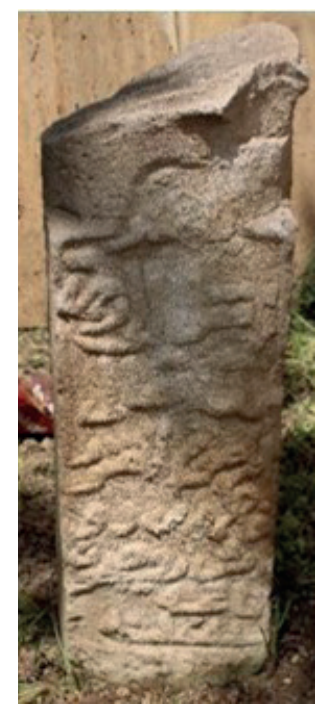

F. 16: Katalog No 14

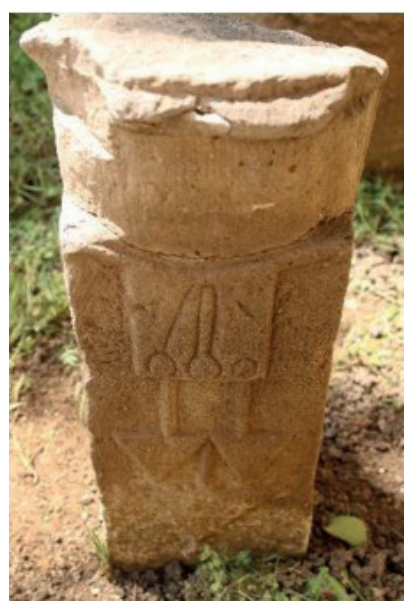

F. 17: Katalog No 14

Katalog No: 15

Bulunduğu Müze: Arkeoloji Müzesi

Müzeye Getirildiği Yer: Okul deposu

Ölçüleri (cm.): En: 16 Boy: 16 Kalınlık: 62 
İşleniş Tekniğgi: Kabartma

Kitabesi: (Ön yüzey)

\begin{tabular}{|c|c|}
\hline $\begin{array}{l}\text { Ziyaret eyleyen karib ihvan } \\
\text { Bana bir Fatihayı eylesin ihsan } \\
\text { 'Aședen murad bir duadır } \\
\text { Bugün bana ise yarın sanadır. }\end{array}$ & 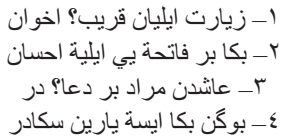 \\
\hline
\end{tabular}

Anlamı: Ziyaret eden yakınlarım ve kardeşlerim bana bir Fatiha okuyarak iyilik etsinler. Yaşayanlardan isteğim bir duadır bugün bana ise yarın sanadır.

Kitabesi: (Arka yüzey)

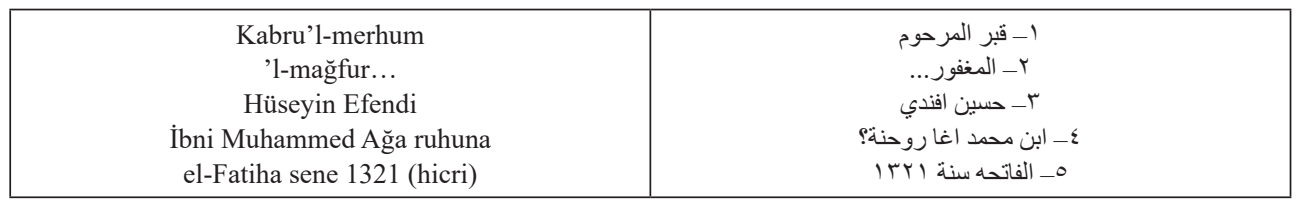

Anlamı: Bu Kabir merhum, mağfur, Muhammed Ağa'nın oğlu Hüseyin Efendi'nindir. Ruhuna el-Fatiha. 1903 senesi

Tanım ve Kompozisyon: Kareye yakın prizmal kesitli ve düşey dikdörtgen gövdeye sahip süslemesiz bir taştır. Taşın ön yüzeyinde ve arka yüzeyinde kabartma tekniğiyle yazılmış kitabe metinlerine yer verilmiştir. Ön yüzeyde satırlar sağa yatık bir şekilde yerleştirilmiştir. Satır aralarında kartuşa yer verilmemiştir (F.18). Dört satırdan oluşan kitabe yalnızca üst ve alt kısma yapılan birer kartuşla sınırlandırılmıştır. Taşın arka yüzeyinde yer alan kitabe metni düz bir şekilde yapılmış ve düz kartuşlarla birbirinden ayrılmıştır. Metin beş satırdan oluşmaktadır (F.19). 


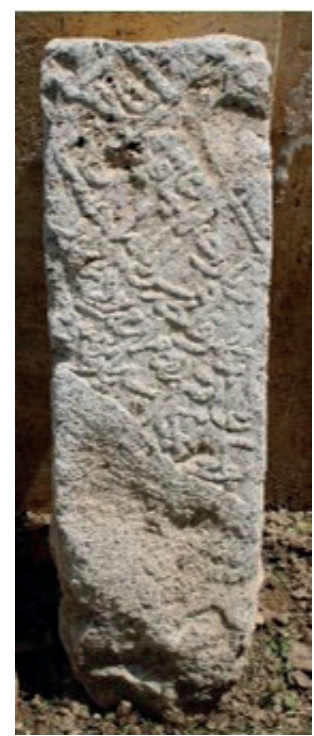

F. 18: Katalog No 15

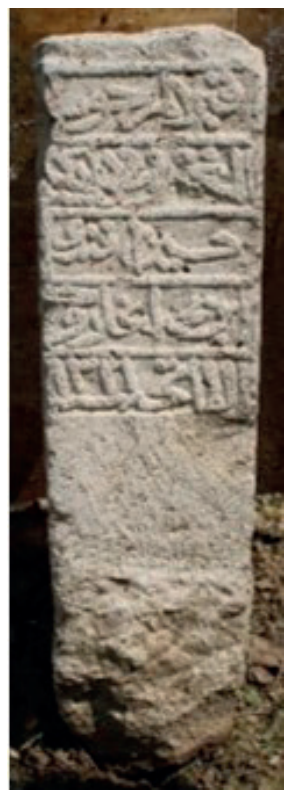

F. 19: Katalog No 15

Katalog No: 16

Bulunduğu Müze: Etnoğrafya Müzesi

Müzeye Getirildiği Yer: Satın alma 
Ölçüleri (cm.): En: 20 Boy:68 Kalınlık: 8,5

İşleniş Tekniği: Kabartma

Kitabesi:

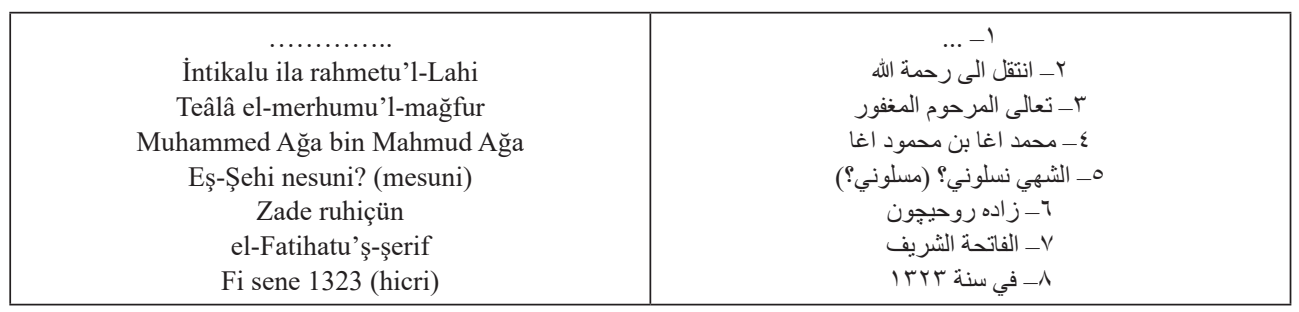

Anlamı: ... şanı yüce her şeye gücü yeten Allah'ın rahmetine muhtaç merhum ve mağfur, Nesuni? (Mesuni?) zade Mahmut Ağa oğlu Muhammed Ağa'nın ruhu için el-Fatiha-yı şerife. 1905 yılında

Tanım ve Kompozisyon: Dikdörtgen kesitli, düşey dikdörtgen gövdeye sahip olan taşın üst kısmı kırılmıştır. Taşın kalan kısmında yedi satırlık kitabe metni bulunmaktadır. Kabartma tekniğinde işlenmiş olan kitabe satırları taşın yüzeyine sağa doğru yatay bir şekilde yerleştirilmiştir. Satırlar birbirinden kartuşlarla ayrılmıştır (F.20).

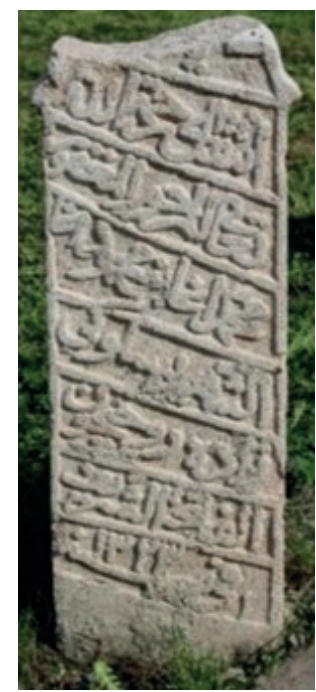

F. 20: Katalog No 16

Katalog No: 17

Bulunduğu Müze: Arkeoloji Müzesi

Müzeye Getirildiği Yer: Okul deposu

Ölçüleri (cm.): En: 18,5 Boy: 61 Kalınlık: 18,5 
İşleniş Tekniğgi: Kabartma

Kitabesi:

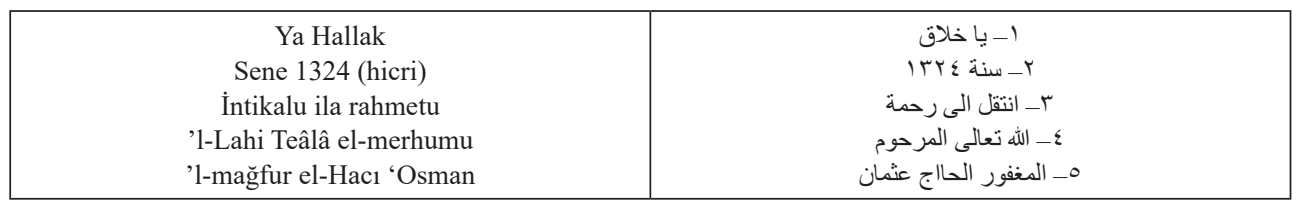

Anlamı: Ey her şeyi Yaratan! Sene 1906 (miladi). Şanı yüce her şeye gücü yeten Allah’ın rahmetine intikal eden Hacı Osman

Tanım ve Kompozisyon: Kareye yakın prizmal kesitli ve düşey dikdörtgen gövdeye sahip olan taş, başlıklı olarak tamamlanmıştır. Çatal Kalafat ${ }^{10}$ olarak adlandırılan başlık kısmı taşın gövde kısmına oturmaktadır. Taşın yüzeyinde beş satırlık kitabe metni yer almaktadır. Kitabe satırları kartuşlarla birbirinden ayrılmıştır. Kitabenin ilk satırı üst kısımda üç kenarlı bir kartuşla sınırlandırılmıştır (F.21).

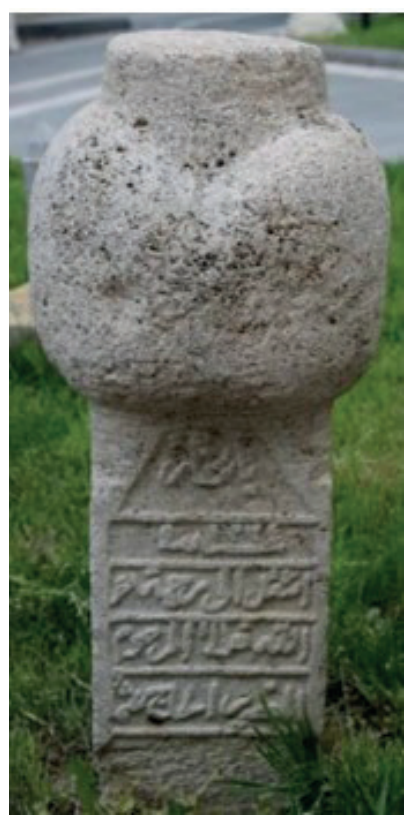

F. 21: Katalog No 17

10 İşli, a.g.e., s. 126-129. 
Katalog No: 18

Bulunduğu Müze: Arkeoloji Müzesi

Müzeye Getirildiği Yer: Okul deposu

Ölçüleri (cm.): En: 24 Boy: 66 Kalınlık: 12

İşleniş Tekniği: Kabartma

Kitabesi:

\begin{tabular}{|c|c|}
\hline $\begin{array}{c}\text { Haza el-merhum } \\
\text { El mağfur Oksuz } \\
\text { Oğli kerimesi Amine } \\
\text { Ruhi içün } \\
\text { el-Fatiha } \\
\text { Sene 1330 Ramadan (hicri) }\end{array}$ & 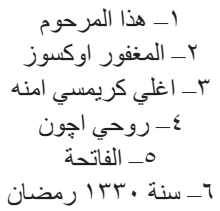 \\
\hline
\end{tabular}

Anlamı: Bu merhum ve mağfur Öksüzoğlu kerimesi (kızı) Amine'nin ruhu için el-Fatiha. Kasım/Aralık 1912 (miladi)

Tanım ve Kompozisyon: Dikdörtgen kesitli ve düşey dikdörtgen gövdeye sahip olan taş üçgen formlu alınlık şeklinde tamamlanmıştır. Gövde kısmı dar olan taşın alınlık kısmı daha geniş yapılmıştır. Eserin alınlık kısmında altı satırdan oluşan kitabe işlenmiştir. Kabartma tekniğinde işlenmiş olan kitabe satırları arasında kartuşa yer verilmemiştir (F.22).

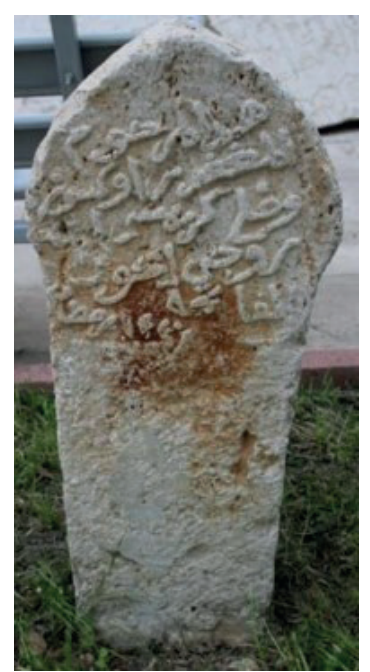

F. 22: Katalog No 18 
Katalog No: 19

Bulunduğu Müze: Arkeoloji Müzesi

Müzeye Getirildiği Yer: Okul deposu

Ölçüleri (cm.): En: 18,5 Boy: 66 Kalınlık: 18,5

İşleniş Tekniği: Kabartma

Kitabesi: (Ön yüzey)

\begin{tabular}{|c|c|}
\hline $\begin{array}{c}\text { Ya Ğaffar } \\
\text { İntikalu ila rahmetu'l-Lahi } \\
\text { El-merhumu'l-mağfuru'l-'Alimu } \\
\text { 'l-‘Akilu'l-Mudakkiku } \\
\text { 'l-Fazıl Eş-Şeyh Mahmud } \\
\text { Haki Efendi ibni } \\
\text { Mustafa el-Arif } \\
\text { Bekerdi? Zade liruhihi }\end{array}$ & 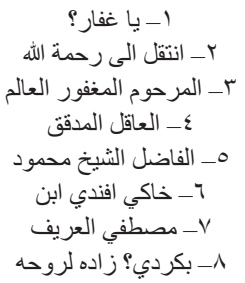 \\
\hline
\end{tabular}

Anlamı: Ey mağfiret eden. Allah'ın rahmetine intikal etmiş olan merhum mağfur, Alim, Akıllı insan, üstün müdekkik (tetkik eden), Bekerdi? Zade Mustafa oğlu Şeyh Mahmut Haki Efendi'nin ruhuna.

Kitabesi: (Arka yüzey)

\begin{tabular}{|c|c|}
\hline $\begin{array}{c}\text { Ya Settar } \\
\text { Rehber-i Şem'i takiyye-yi muhter iden ol } \\
\text { Pend-i nush edip halkı gına } \\
\text { Ah-1 furketle dedim tarihi ferd } \\
\text { Haki ğefereyle 'ata yeşermuyi? }\end{array}$ & 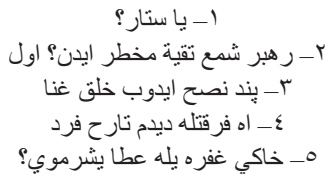 \\
\hline
\end{tabular}

Anlamı: Ey koruyan. Takva ışığının rehberi, ihtar eden o, halkı çokça nasihat ve öğüt eden kişinin, ayrılık ahıyla tarihini dedim ki, Haki affeyle "ğefere eyle"" ...

Tanım ve Kompozisyon: Kareye yakın prizmal kesitli ve düşey dikdörtgen gövdeye sahip olan taşın başlık kısmı kırılmıştır. Taşın ön yüzeyinde sekiz satırlık kitabe yer almaktadır (F.23). Kitabenin ilk satırı taşın boyun kısmında işlenmiştir. Kalan yedi satır eserin gövde kısmında yer almaktadır. Kabartma tekniğiyle işlenmiş olan kitabe satırları birbirlerinden kartuşlarla ayrılmıştır. Taşın arka yüzeyinde ise beş satırlık kitabe vardır. Kitabenin ilk satırı taşın boyun kısmında badem şeklinde bir kartuş içerisinde işlenmiştir. Diğer dört satı rise taşın gövde kısmındadır. Sağa doğru hafif yatay bir şekildeyazılmış olan kitabe satırları arasında kartuşa yer verilmemiştir (F.24).

11 Burada sanatkâr tarafindan ebced hesabıyla tarih düşülmüş. "ğefere eyle" kelimesiyle tarih oluşturulmuştur ki bu da 1330 (hicri) 1912 (miladi) tarihine denk gelmektedir. 


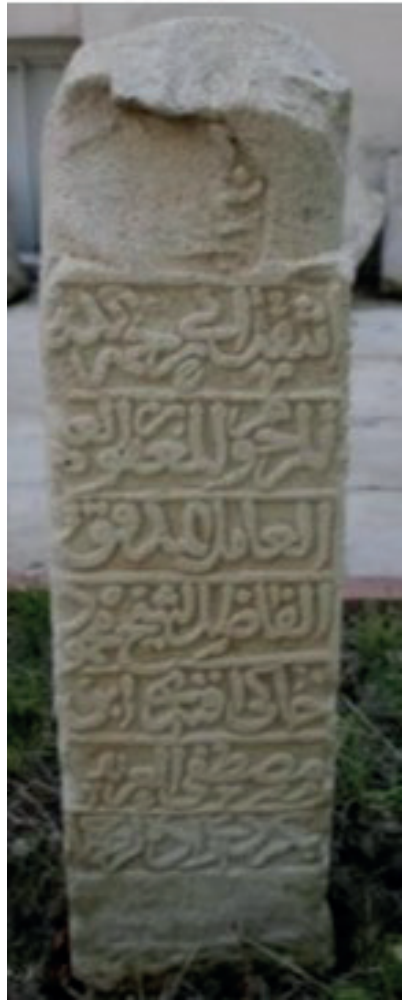

F. 23: Katalog No 19

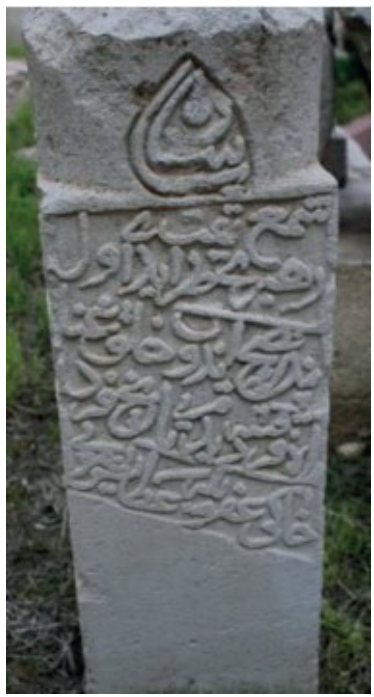

F. 24: Katalog No 19 
Katalog No: 20

Bulunduğu Müze: Arkeoloji Müzesi

Müzeye Getirildiği Yer: Kırklar Mezarlığ 1

Ölçüleri (cm.): En: 39,5 Boy: 51 Kalınlık: 9

İşleniş Tekniği: Kabartma

Kitabesi:

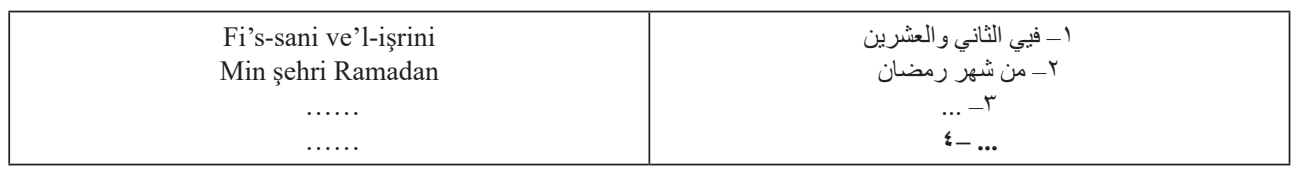

Anlamı: Ramazan ayının yirmi üçünde...

Tanım ve Kompozisyon: Alt kısmı kırık olan taş, dikdörtgen kesitli ve düşey dikdörtgen gövdeye sahiptir. Taşın ön yüzeyinde kalan kısmında dört satırlık kitabe vardır (F.25). Kabartma tekniğiyle işlenmiş olan kitabe satırları birbirlerinden kartuşlarla ayrılmıştır. Taşın arka yüzeyi, iç içe yapılmış iki silmeyle sınırlandırılmıştır. Silmelerden sonra orta kısımda sitilize edilmiş bitkisel motiflerle taş tamamlanmıştır (F.26).

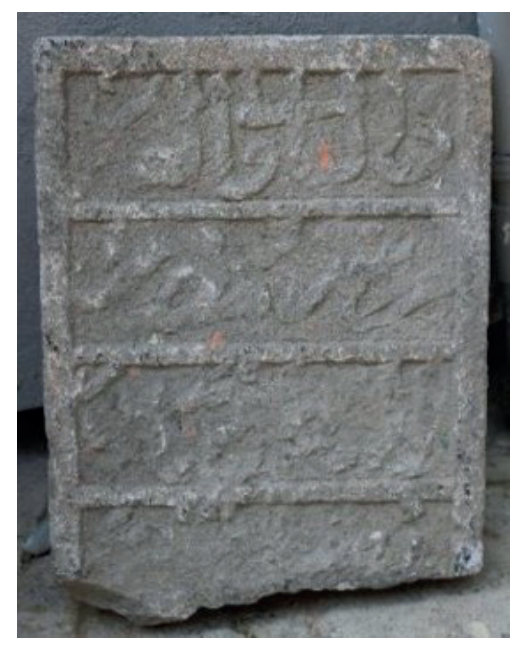

F. 25: Katalog No 20 


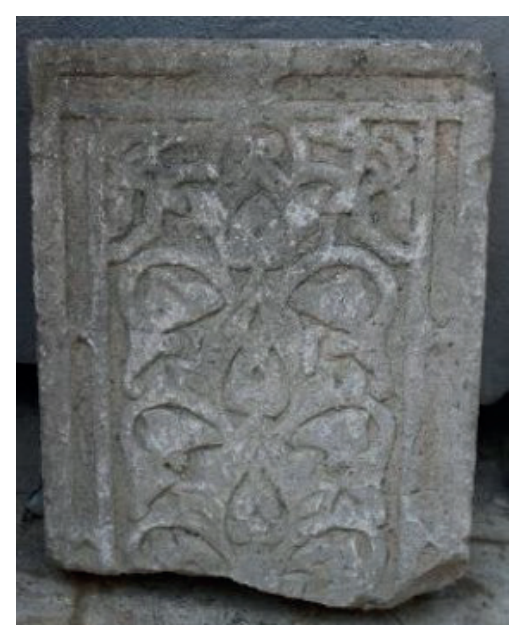

F. 26: Katalog No 20

Katalog No: 21

Bulunduğu Müze: Arkeoloji Müzesi

Müzeye Getirildiği Yer: Kırklar Mezarlığı

Ölçüleri (cm.): En: 46 Boy: 47 Kalınlık: 10

İşleniş Tekniği: Kabartma

Kitabesi: (Rahman Suresi 26. ve 27. Ayetleri)

\begin{tabular}{|c|c|}
\hline $\begin{array}{c}\text { Allah } \\
\text { Kullu men 'aleyhâ fân ve yebka ve } \\
\text { chu Rabbike zu'l-celali ve'l } \\
\text { i(kram) }\end{array}$ & 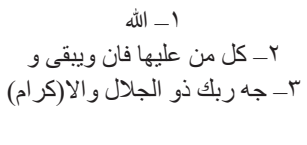 \\
\hline
\end{tabular}

Anlamı: Allah, Yer üzerinde bulunan her canlı yok olacaktır. Ancak azamet ve ikram sahibi Rabbinin zâtı bâki kalacaktır.

Tanım ve Kompozisyon: Alt kısmı kırık olan taş, dikdörtgen kesitli ve düşey dikdörtgen gövdelidir. Taşın ön yüzeyinde üç satırlık kitabe kalmıştır. Kabartma tekniğinde işlenmiş olan kitabe satırları birbirinde kartuşlarla ayrılmıştır (F.27). Kitabenin ilk satırı üst kısımdan yarım oval bir kartuşla sınırlandırılmıştır. Oval kartuşun dış kısmında köşelerde birer çarkıfelek motifi işlenmiştir. Taşın arka yüzeyinde; üstten ip gibi verilmiş muhtemelen zincirle asılı duran bir kandil motifi tasvir edilmiştir. Kandil geniş ağızlı olup, ağzından fitili çıkmaktadır. Gövdesi süslemesiz olarak işlenen kandilin her iki yanından kandili asmak için kullanılan zincirler uzanmaktadır. Zincirlerin her iki yanında birer çarkıfelek motifi yapılmıştır. Motifler alttan yukarıya doğru daralan şekiller üzerine oturtulmuştur. Bu şekillerin yanlarında ve kandilin iç 
kısmında damla motifleri işlenmiştir. Kandil, üst kısımda sivri bir kemerle sınırlandırılmıştır. Kemerin köşelerinde çarkıfelek motifleri tekrar edilmiştir (F.28a, F.28b).

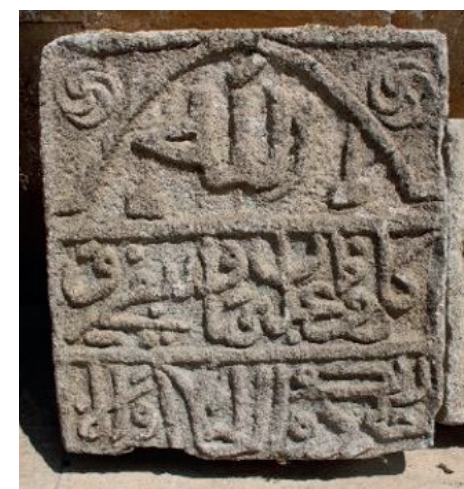

F. 27: Katalog No 21

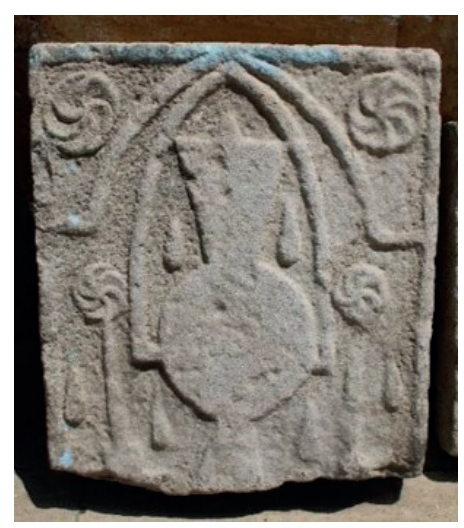

F. 28a: Katalog No 21

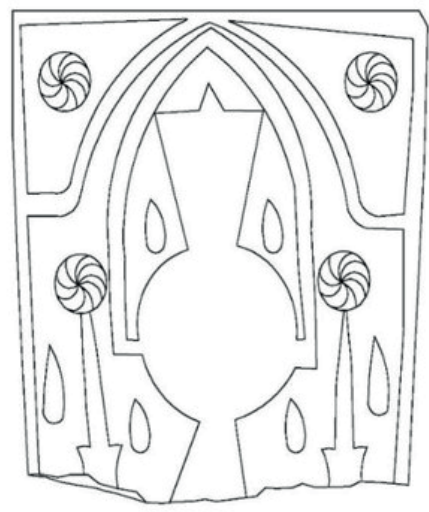

F. 28b: Katalog No 21

Katalog No: 22

Bulunduğu Müze: Arkeoloji Müzesi

Müzeye Getirildiği Yer: Kırklar Mezarlığı

Ölçüleri (cm.): En: 89 Boy: 31 Yükseklik: 24

İşleniş Tekniği: Kabartma

Kitabesi: (Lahtin sağlam kalan uzun kenar yüzeyi)

Ve men te'kulu min külli teyyibe illa

1 - ومن تأكلوا من كل طيبة الا

Anlamı: Ve sadece iyi ve güzel olandan yiyin ${ }^{12}$

12 Birebir aynı metin olmasa da Bakara Suresi 57. Ayeti kerimesi gibi Kur'an’1 Kerim’in birkaç yerinde geçen 
Kitabesi: (Lahtin üst kısmı)

Anlamı: Şanı yüce olan Allah'ın rahmeti ve bereketi onlara olsun

Tanım ve Kompozisyon: Lahit tipi mezar ${ }^{13}$ şeklinde düzenlenmiştir. Lahtin ayakta kalan kısmında kabartma tekniğinde işlenmiş kitabe metinlerine yer verilmiştir. Uzun kenarda, taşın yüzeyi boyunca devam eden tek satırlık kitabe yer almaktadır (F.29). Lahtin üst kısmında yine taşın yüzeyi boyunca tek sıra şeklinde geometrik süsleme olan zincir motifi işlenmiştir. $\mathrm{Bu}$ motifin her iki ucunda birer tane üst yüzleri geometrik bezemeli sekizgen prizmal çıkıntılar yapılmıştır. Üst kısımdaki zincir motifinin yanında yine tek satırlık kitabe bulunmaktadır (F.30).

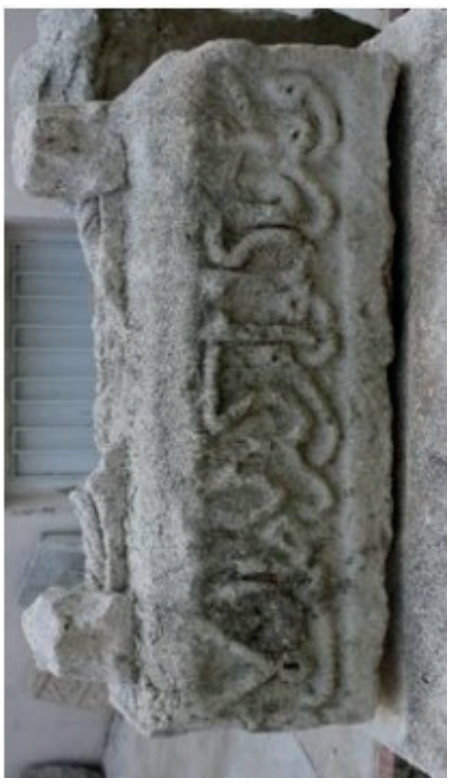

F. 29: Katalog No 22 


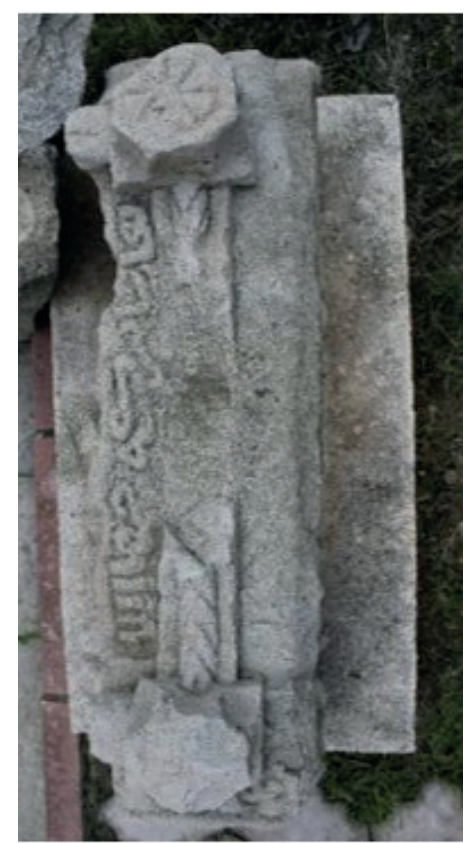

F. 30: Katalog No 22

Katalog No: 23

Bulunduğu Müze: Arkeoloji Müzesi

Müzeye Getirildiği Yer: Kırklar Mezarlığı

Ölçüleri (cm.): En: 42,5 Boy: 35 Kalınlık: 8,5

İşleniş Tekniği: Kabartma

Kitabesi: (Al-i İmran Suresi 18. Ayeti)

\begin{tabular}{|c|c|}
\hline $\begin{array}{c}\text { Şehidallâhu ennehû } \\
\text { lâ ilâhe illâ hûve } \\
\text { vel melâiketu } \\
\text { (ve ulul 'ilmi kâimen bi'l-kist, lâ ilâhe illâ huvel azîzul } \\
\text { hakîm.) }\end{array}$ & 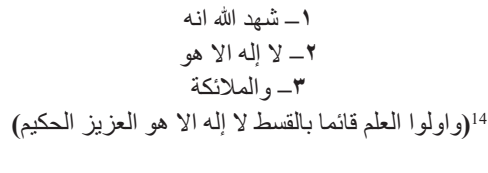 \\
\hline
\end{tabular}

Anlamı: Allah, melekler ve ilim sahipleri, ondan başka ilah olmadığına adaletle şâhitlik ettiler. Ondan başka ilah yoktur. O, mutlak güç sahibidir, hüküm ve hikmet sahibidir.

Tanım ve Kompozisyon: Dikdörtgen kesitli, düşey dikdörtgen gövdeye sahip olan taşın hem alt hem üst kısımları kırıktır. Kalan kısımda taşın yüzeyi üç dilim şeklinde düzenlenmiştir. Ortada

14 Al-i İmran Suresi 18. Ayeti kerimesinin “melaiketu” lafzına kadar olan kısım taşa hakkedilmiştir. Ayet bütünlüğü sağlaması açısından ayetin tamamı yazılmıştır. Taşa hakkedilmeyen kısım parantez içinde gösterilmiştir. 
yuvarlak kemer, yanlarda birer yarım daire kemere yer verilmiştir. Yarım daire kemerlerin kavisleri içe doğru yapılarak taca benzer bir biçim verilmiştir ${ }^{15}$. Tac kısmının ortasında yuvarlak kemerli bölümde kitabe metni yer almaktadır. Kabartma tekniğiyle işlenmiş olan kitabe satırları birbirlerinden kartuşlarla ayrılmıştır. Tac kısmının yanlarında bitkisel motif olan sarmaşığa yer verilmiştir (F.31).

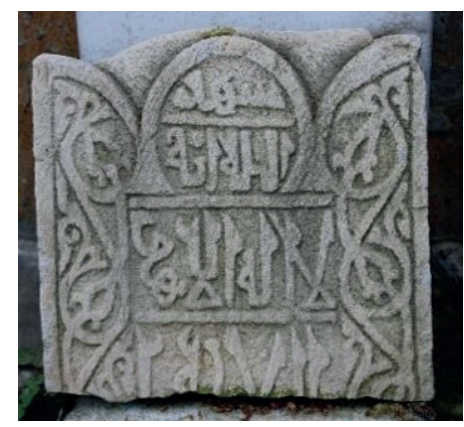

F. 31: Katalog No 23

Katalog No: 24

Bulunduğu Müze: Arkeoloji Müzesi

Müzeye Getirildiği Yer: Okul deposu

Ölçüleri (cm.): En: 31 Boy: 42 Kalınlık: 8

İşleniş Tekniği: Kabartma

Kitabesi:

\begin{tabular}{|c|c|}
\hline Muhammed ce'elella & محمد جعله الله \\
\hline
\end{tabular}

Anlamı: Allah yaptı Muhammed

Tanım ve Kompozisyon: Dikdörtgen kesitli ve düşey dikdörtgen gövdeye sahip olan taş üst ve alt kısımlardan kırıktır. Taşın yüzeyinde kabartma tekniğinde yazılmış tek satır kitabesi kalmıştır. Kitabenin her iki yanına geometrik şekiller yapılmıştır (F.32).

15 Çal, a.g.m., s.76. 


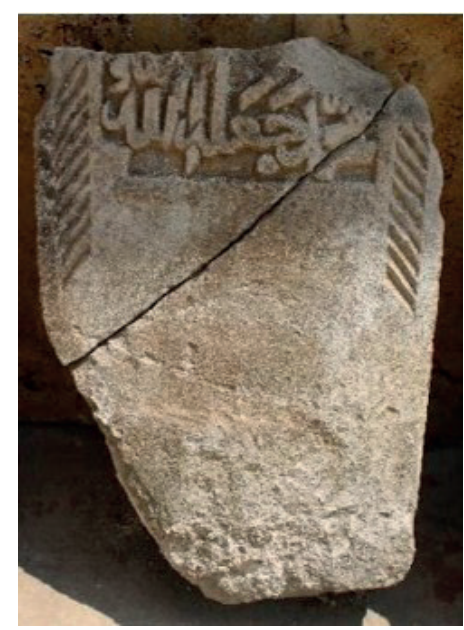

F. 32: Katalog No 24

Katalog No: 25

Bulunduğu Müze: Arkeoloji Müzesi

Müzeye Getirildiği Yer: Kırklar Mezarlığı

Ölçüleri (cm.): En: 33,5 Boy: 34 Kalınlık: 7

İşleniş Tekniği: Kabartma

Kitabesi:

(el-mer) humu'ş-şehidu Hüseyin Beg Emir? el-Ahir en-Nazır

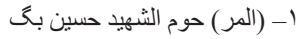

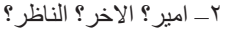

Anlamı: Şehid, merhum Hüseyin Bey, son emir (bey) Nazır (bakan veya idareci)

Tanım ve Kompozisyon: Gövdenin büyük kısmı kırık olan taş, dikdörtgen kesitli ve düşey dikdörtgen gövdelidir. Taşın ön yüzeyinde ortada bir kartuşla ayrılmış, kabartma tekniğinde işlenmiş iki satırlık kitabe kalmıştır (F.33). Kitabenin her iki kenarında yapılmış olan geometrik şekillerle kitabe sınırlandırılmıştır. Taşın arka yüzeyine sitilize edilmiş çiçek ve yaprak motifleri işlenmiştir. Taş, her iki kenardan baklava şekilleri olan geometrik şekillerle sınırlandırılmıştır. İç kısmında alttan yukarıya doğru uzanan üst üste işlenmiş sitilize çiçek motifleri yapılmıştır. Bu motiflerin her iki yanında ise aralarda sitilize edilmiş iç içe işlenmiş yapraklar ve sarmaşık motifleri ile taşın süsleme kompozisyonu tamamlanmıştır (F.34). 


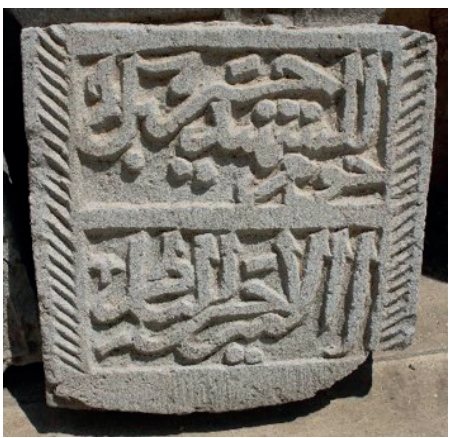

F. 33: Katalog No 25

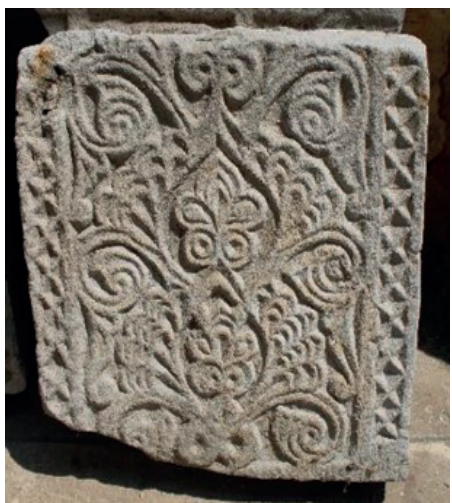

F. 34: Katalog No 25

Katalog No: 26

Bulunduğu Müze: Arkeoloji Müzesi

Müzeye Getirildiği Yer: Okul deposu

Ölçüleri (cm.): En: 34 Boy: 35 Kalınlık: 8

İşleniş Tekniği: Kabartma

Kitabesi:

Es-Sin? Fi

Şehr? Allahi
ا- إ- الصن؟ في

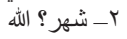

Anlamı: Allah'ın ayında?

Tanım ve Kompozisyon: Dikdörtgen kesitli ve düşey dikdörtgen gövdeli olan taşın büyük kısmı kırıktır. Taşın ön yüzeyinde yıpranmış olan iki satırlık, kabartma tekniğinde 
işlenmiş, ortada bir kartuşla ayrılmış kitabe kalmıştır (F.35). Taşın arka yüzeyide ön yüzeyde olduğu gibi yıpranmıştır. Kalan izlerden yüzeyde bitkisel bir motifin işlendiği anlaşılmaktadır (F.36).

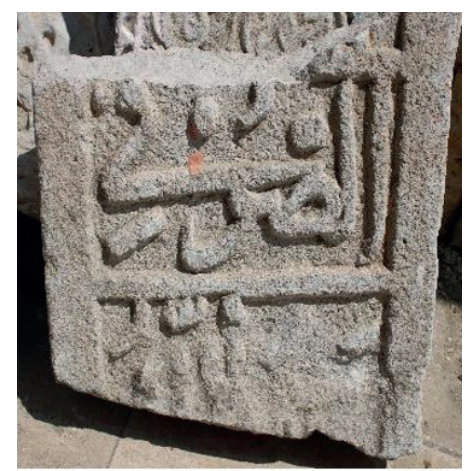

F. 35: Katalog No 26

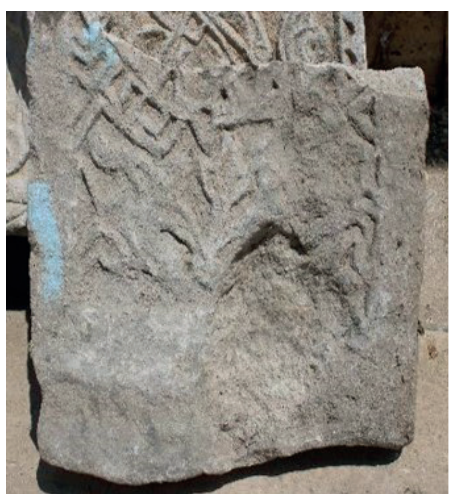

F. 36: Katalog No 26

Katalog No: 27

Bulunduğu Müze: Arkeoloji Müzesi

Müzeye Getirildiği Yer: Okul deposu

Ölçüleri (cm.): En: 40,5 Boy: 45,5 Kalınlık: 8,5

İşleniş Tekniği: Kabartma

Kitabesi:

\begin{tabular}{|c|c|}
\hline $\begin{array}{c}\text { Tuvuffiye ila rahmetu'l-Lahi } \\
\text { Teâla } \\
\ldots \ldots \ldots . .\end{array}$ & 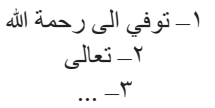 \\
\hline
\end{tabular}

Anlamı: Şanı yüce her şeye gücü yeten Allah’ın rahmetine (erişti). Vefat etti. 
Tanım ve Kompozisyon: Dikdörtgen kesitli ve düşey dikdörtgen gövdeye sahip olan taşın alt kısmı kırıktır. Taşın ön yüzeyinde kabartma tekniğiyle yazılmış iki satırlık kitabe kalmıştır (F.37). Birbirlerinden ince bir kartuşla ayrılan kitabe, dıştan içe doğru iç içe yapılmış üç silme ile çevrelenmiştir. İlk satırdan kartuşla ayrılan ikinci satır iç içe yapılmış üç dilimli kemer formunda bir silmeyle sınırlandırılmıştır. İç kısımdaki kemer formu kartuşun üzerine otururken ikinci kemer formu köşelerde kıvrılarak spiral şeklinde sonlandırılmıştır. Kitabe satırını çevreleyen bu kemerin köşelerinde sitilize edilmiş birer çiçek motifi işlenmiştir.

Taşın arka yüzeyi bitkisel motiflerle süslenmiştir. Süsleme kompozisyonuna geçmeden önce taş, ince bir silmeye çevrelenmiştir. Taşın kırık olan alt kısmında yarım bir çiçek motifi vardır. Bu motiften yukarıya doğru uzanan üzüm yaprakları yapılmıştır (F.38a, F38b).

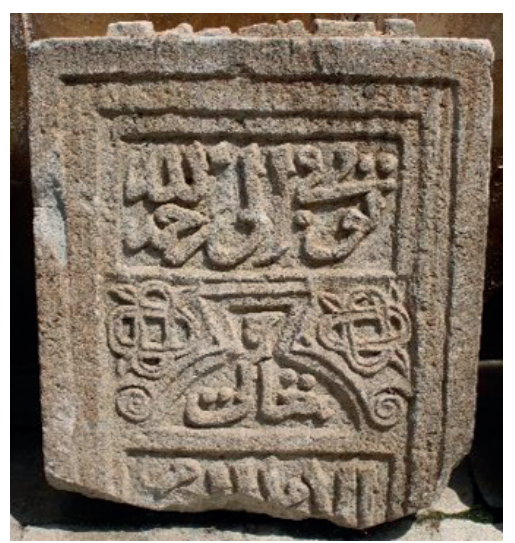

F. 37: Katalog No 27

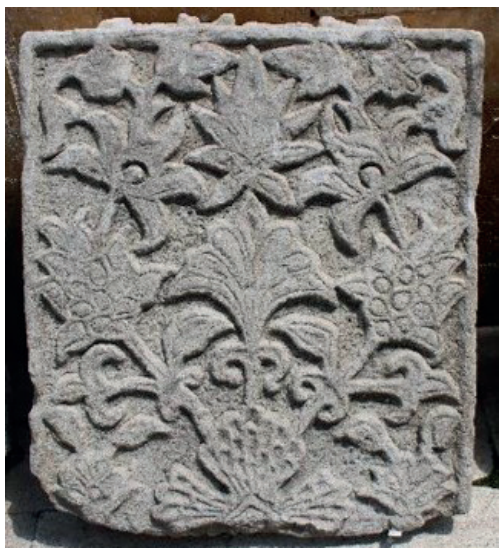

F. 38a: Katalog No 27

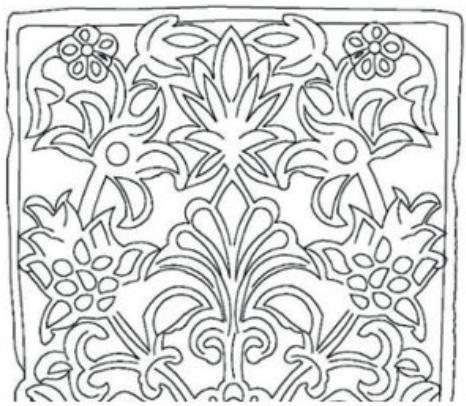

F. 38b: Katalog No 27 
Katalog No: 28

Bulunduğu Müze: Arkeoloji Müzesi

Müzeye Getirildiği Yer: Okul deposu

Ölçüleri (cm.): En: 36 Boy: 49 Kalınlık: 8

İşleniş Tekniği: Kabartma

Kitabesi:

\begin{tabular}{|c|c|}
\hline $\begin{array}{c}\text { Ente'l-Baki } \\
\text { İntikali ila rahmetu'l-Lahi } \\
\text { El-merhum el-Hacı }\end{array}$ & 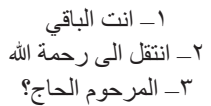 \\
\hline
\end{tabular}

Anlamı: Sen Baki olansın! Allah'ın rahmetine erişti. Hacı...

Tanım ve Kompozisyon: Alt kısmı kırık olan taş, dikdörtgen kesitli ve düşey dikdörtgen gövdeye sahiptir. Dıştan içe doğru iç içe üç silme ile çevrilmiş olan taşın yüzeyinde üç satırlık kitabe metni kalmıştır. Kabartma tekniğinde yazılmış olan kitabe satırları birbirlerinden kartuşlarla ayrılmışlardır. Kitabenin ilk ve kalan son satırı süslemesiz bırakılmışken ortada yer alan satır hem daha geniş hem de süsleme programına yer verilmiş bir satırdır. Bu satır, alt kısımda yazı kuşağı, yazı kuşağını çevreleyen dilimli bir kemerle başlamaktadır. Dilimli kemer orta kısımda düğüm yaparak birleşmektedir. Bu düğümün her iki kenarında ise birer bulut motifi işlenerek kompozisyon tamamlanmıştır (F.39).

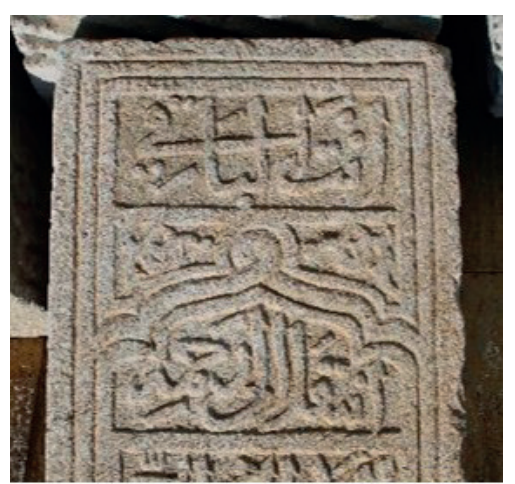

F. 39: Katalog No 28

Katalog No: 29

Bulunduğu Müze: Arkeoloji Müzesi

Müzeye Getirildiği Yer: Kırklar Mezarlığ 1

Ölçüleri (cm.): En: 35,5 Boy: 68 Kalınlık: 6

İşleniş Tekniği: Kabartma 
Kitabesi:

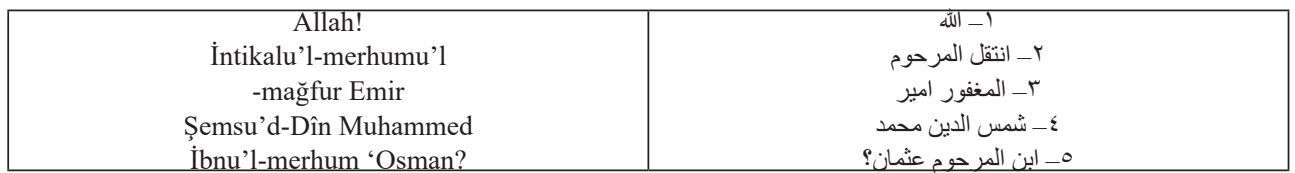

Anlamı: Allah. Ahirete intikal etmiş olan merhum mağfur. Rahmetli Osman'ın oğlu Emir Şemseddin Muhammed

Tanım ve Kompozisyon: Dikdörtgen kesitli ve düşey dikdörtgen gövdeye sahip olan taş, üçgen formlu alınlık şeklinde tamamlanmıştır. Taşın ön yüzeyinde beş satırlık kitabe metni yer almaktadır. Kabartma tekniğinde işlenmiş olan kitabe satırları birbirlerinden kartuşlarla ayrılmaktadır (F.40). Taşın arka yüzeyi dıştan ince bir silme ile sınırlandıktan sonra orta kısmında süsleme kompozisyonu uygulanmıştır. Kompozisyonda iki iple asılı duran, fitili yanan, geniş kavis yapan ağzı, ince boyunlu, dairesel şişkin gövdeli yanan bir kandil betimlenmiştir. Kandilin her iki yanında birer şamdan yanar şekilde işlenmiştir. Şamdanların kaide kısmında her iki kenarlarında da dışa doğru çıkıntı yapan şekiller işlenerek, şamdanı tutmak için birer tutamaç yapılmıştır. Şamdanların üst kısımlarında birer çarkıfelek şeklinde yapılmış rozet çiçekleri dikkati çekmektedir (F.41a, F41b).

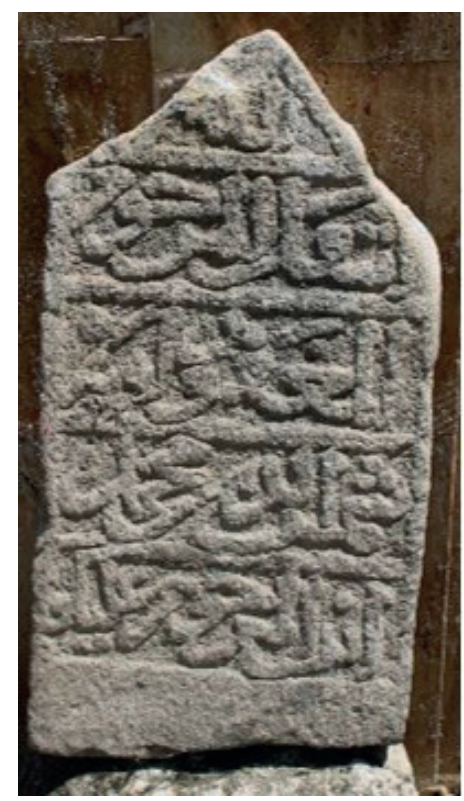

F. 40: Katalog No 29 


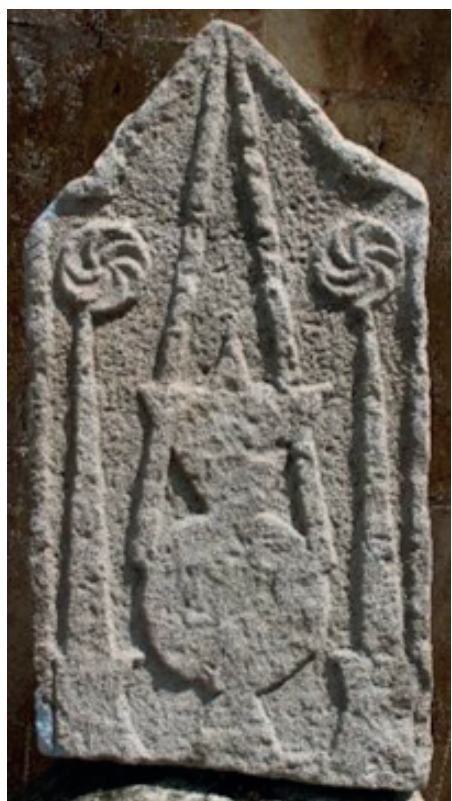

F. 41a: Katalog No 29

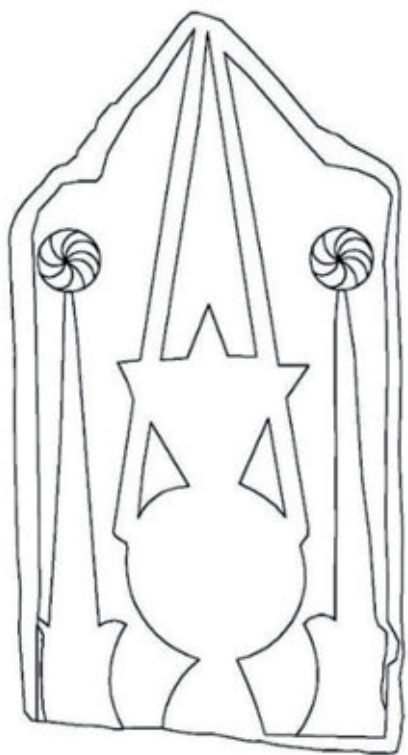

F. 41b: Katalog No 29

Katalog No: 30

Bulunduğu Müze: Arkeoloji Müzesi

Müzeye Getirildiği Yer: Okul deposu

Ölçüleri (cm.): En: 36 Boy: 79 Kalınlık: 11,5

İşleniş Tekniğgi: Kabartma

Kitabesi:

\begin{tabular}{|c|c|}
\hline $\begin{array}{c}\text { İntikalu ila rahmetu'l-Lahi } \\
\text { El-Kerimu'l-merhum } \\
\text { Hacı Mahmud bin } \\
\text {........ }\end{array}$ & 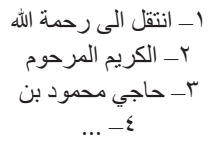 \\
\hline
\end{tabular}

Anlamı: Allah'ın rahmetine intikal etmiş, kerim, merhum... oğlu Hacı Mahmud'un (kabri)

Tanım ve Kompozisyon: Dikdörtgen kesitli ve düşey dikdörtgen gövdeye sahip bir taştır. Taşın ön yüzeyinde dört satırlık kitabe metni yer alır (F.42). Kabartma tekniğiyle yazılmış olan kitabe metni satırları kartuşlarla birbirinden ayrılmıştır. Kitabenin son satırı zarar gördüğü için okunamamıştır. Taşın arka yüzeyinin etrafı ince bir kartuşla sınırlandırılmıştır (F.43). Yıpranmış olan arka yüzde kalan izlerden taşın bitkisel motiflerle süslendiği anlaşılmaktadır. Taşın sağ ve sol kenarlarını oluşturan dar kenarlarda geometrik şekil olan baklava dilimleri iç içe işlenmiştir (F.44). 


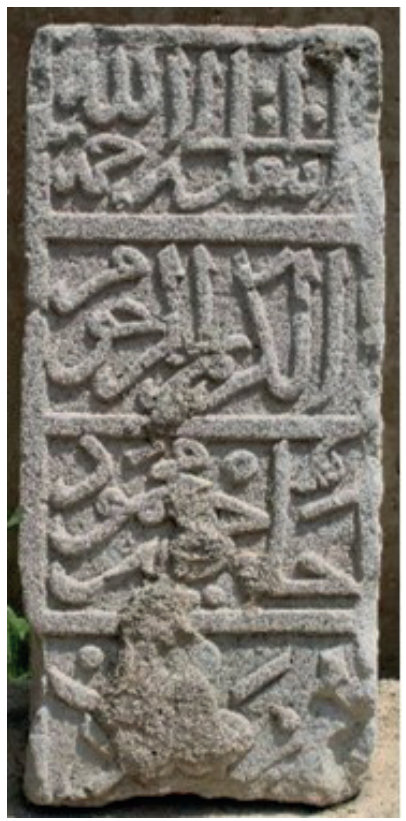

F. 42: Katalog No 30

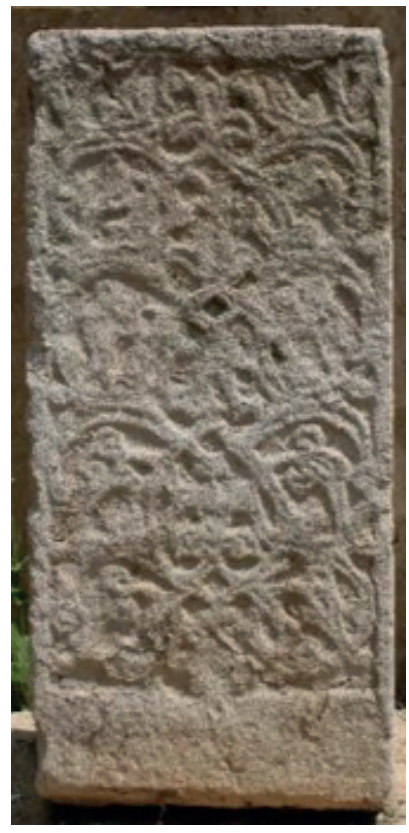

F. 43: Katalog No 30 


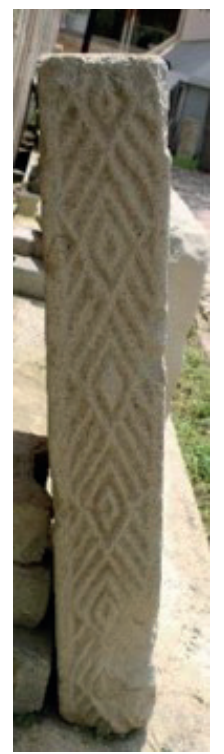

F. 44: Katalog No 30

Katalog No: 31

Bulunduğu Müze: Arkeoloji Müzesi

Müzeye Getirildiği Yer: Okul deposu

Ölçüleri (cm.): En: 40 Boy: 35 Kalınlık: 10,5

İşleniş Tekniğgi: Kabartma

Kitabesi:

Bi'l-Mulku's-Samedu'1 'l-A'ala

Anlamı: Es-Samed (Hiçbir şeye ihtiyacı olmayan her şeyin ona muhtaç) olanın yüce mülkü ile

Tanım ve Kompozisyon: Taş, dikdörtgen kesitli ve düşey dikdörtgen gövdeye sahiptir. Eser kırık olduğu için kitabenin kaç satırdan oluştuğu tespit edilememiştir. Yanlızca alt kısımda yer alan kabartma tekniğiyle işlenmiş son iki satır okunabilmektedir. Bu iki satır üstten düz, alttan ise yarım yuvarlak bir kartuşla çevrelenmiştir. Kartuş içerisinde son satırın bittiği kısımda yukarıya doğru uzanan yaprak motifleri işlenmiştir. Alt kısımda yarım yuvarlak kartuşun etrafını yine yarım yuvarlak formlu bir süsleme kuşağı çevrelemektedir. Bu kuşakta, sitilize edilmiş yaprak motifleri birbirine bağlı sonsuzluk prensibiyle işlenmiştir (F.45). 


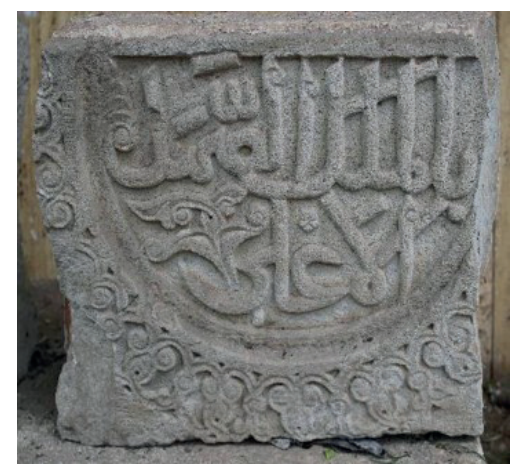

F. 45: Katalog No 31

Katalog No: 32

Bulunduğu Müze: Arkeoloji Müzesi

Müzeye Getirildiği Yer: Okul deposu

Ölçüleri (cm.): En: 15,5 Boy: 41 Kalınlık: 15,5

İşleniş Tekniği: Kabartma

Kitabesi:

\begin{tabular}{|c|c|}
\hline $\begin{array}{l}\text { El-merhumu'l-mağfur } \\
\text { Mahmud bin } \\
\text { Muhammed ruhuna } \\
\text { el-Fatiha }\end{array}$ & 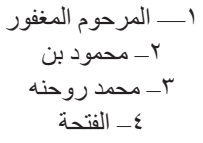 \\
\hline
\end{tabular}

Anlamı: Merhum, mağfur Muhammed oğlu Mahmud'un ruhuna el-Fatiha

Tanım ve Kompozisyon: Üst kısmı krık olan taş, kareye yakın prizmal kesitli ve düşey dikdörtgen gövdeye sahiptir. Süslemesiz olan taşın yüzeyinde dört satırlık kitabe metni yer almaktadır. Kabartma tekniğinde işlenmiş olan kitabe satırları arasında kartuşa yer verilmemiştir (F.46). 


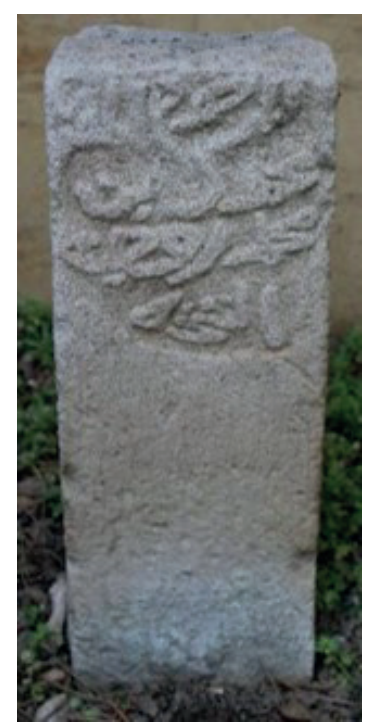

F. 46: Katalog No 32

Katalog No: 33

Bulunduğu Müze: Arkeoloji Müzesi

Müzeye Getirildiği Yer: Okul deposu

Ölçüleri (cm.): En: 39 Boy: 79 Kalınlık: 10,5

İşleniş Tekniği: Kabartma

Kitabesi:

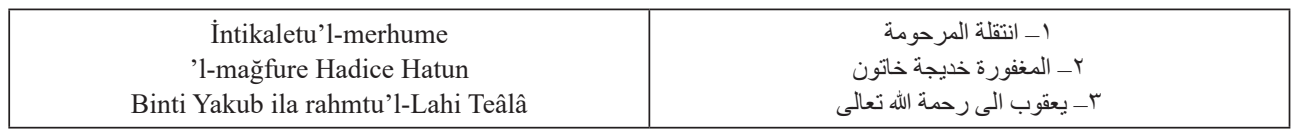

Anlamı: Merhum, mağfur, Yakup kızı Hatice şanı yüce her şeye gücü yeten Allah'ın rahmetine intikal etti

Tanım ve Kompozisyon: Taş, dikdörtgen kesitli ve düşey dikdörtgen gövdeye sahiptir. Taşın ön yüzeyinde üç satırlık kitabe yer alır (F.47). Kabartma tekniğinde işlenmiş olan kitabe satırları birbirlerinden kartuşlarla ayrılmıştır. Taşın arka yüzeyi süslenmiştir. Süsleme üst kısımda basık kemerli bir kartuşla sınırlandırılmıştır. Taşın alt kısmından yukarıya doğru uzanan ortada sitilize edilmiş çiçek motiflerinin her iki yanında palmet ve rumi motifleri ile süsleme tamamlanmıştır (F.48). 


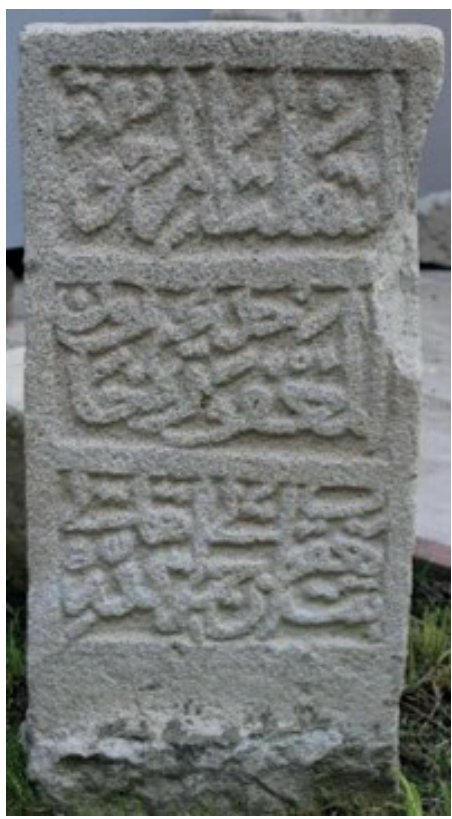

F. 47: Katalog No 33

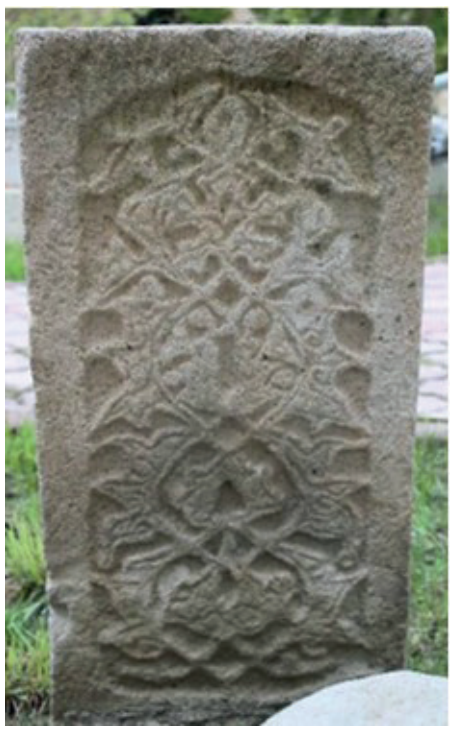

F. 48: Katalog No 33 
Katalog No: 34

Bulunduğu Müze: Arkeoloji Müzesi

Müzeye Getirildiği Yer: Kırklar Mezarlığı

Ölçüleri (cm.): En: 32 Boy: 44 Kalınlık: 9,5

İşleniş Tekniği: Kabartma

Kitabesi:

\begin{tabular}{|c|c|}
\hline $\begin{array}{c}\text { İntikaletu'l-masume } \\
\text {...day Hatun? }\end{array}$ & r - انتقلة المعصومة \\
\hline
\end{tabular}

Anlamı: Masum olan ...day Hatun? İntikal etti

Tanım ve Kompozisyon: Dikdörtgen kesitli, düşey dikdörtgen gövdeye sahip olan taş üç dilimli tepelikle ${ }^{16}$ sonlandırılmıştır. Üç dilimli tepelik alt kısımda bir kartuşla kitabeden ayrılmıştır. Ortada yer alan geniş dilimde yukarıya doğru uzanan yaprak motifleri işlenmiştir (F.49). Geniş dilimin her iki yanında bulunan dilimlerden sağ tarafındaki yıpranmışken, sol kenarda yer alan dilimde yarım bırakılmış yaprak motifi işlenmiştir. Üç dilimli tepelikten sonra taşın kitabe metni yer almaktadır. Alt kısmı kırık olan taş yüzeyinde iki satır kitabe kalmıştır. Kabartma tekniğinde yazılmış olan satırlar birbirlerinden kartuşlarla ayrılmıştır. Taşın arka yüzeyinde süsleme yapılmıştır. Kalan bölümden yüzeyde bir kandil ve kandilin her iki yanında birer şamdan motifi işlendiği anlaşılmaktadır. Kandilin her iki yanında yer alan, kandili asmak için kullanılan birer ip görünümlü zincir yer alır. Bu zincirlerin orta kısmında kandilin genişleyen ağız kısmı ve dışarıya doğru verilmiş fitili işlenmiştir. Kandilin her iki yanında üst kısımları kalmış birer şamdan bulunmaktadır. Şamdanların üzerinde ise birer çarkıfelek motifine yer verilmiştir (F.50a, F50b).

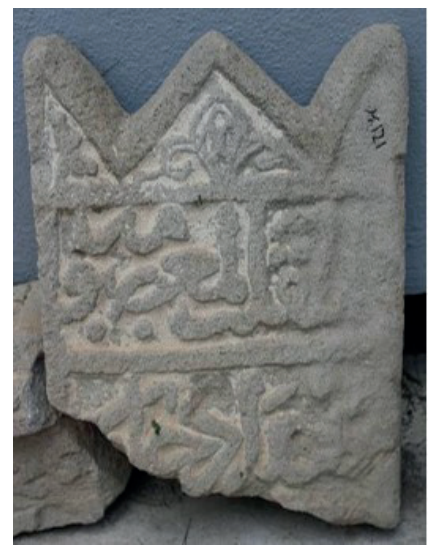

F. 49: Katalog No 34

16 Çal, a.g.m., s.76. 


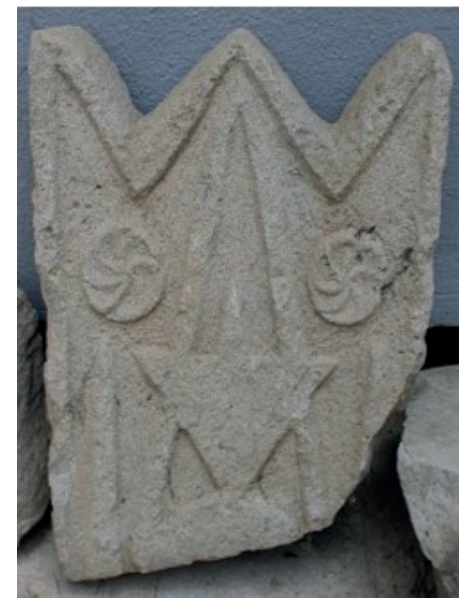

F. 50a: Katalog No 34

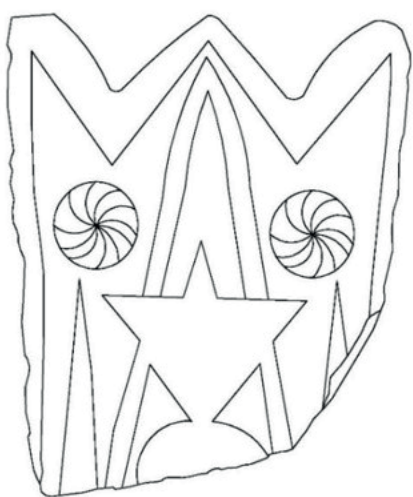

F. 50b: Katalog No 34

Katalog No: 35

Bulunduğu Müze: Arkeoloji Müzesi

Müzeye Getirildiği Yer: Kırklar Mezarlığı

Ölçüleri (cm.): En: 34,5 Boy: 46 Kalınlık: 7,5

İşleniş Tekniği: Kabartma

Kitabesi:

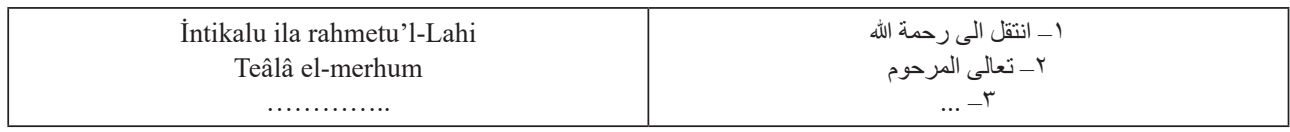

Anlamı: Şanı yüce her şeye gücü yeten Allah'ın rahmetine intikal eden merhum...

Tanım ve Kompozisyon: Dikdörtgen kesitli, düşey dikdörtgen gövdeye sahip olan taş toprağa gömülmüştür. Taşın dışarda kalan yüzeyinde ön kısımda iki satırlık kitabe yer almaktadır (F.51). Kabartma tekniğinde işlenmiş olan kitabe satırları birbirlerinden geniş kartuşlarla ayrılmıştır. Taşın arka yüzeyinde kalan kısımda dışta basik kemerli bir kartuş, kartuşun iç kısmında ise kandil motifinin üst kısmı görülmektedir. İpe benzer zincirlerle her iki yanından asılan kandilin kalan kısmında geometrik motiflerle süslü bir gövde ve yine geometrik motiflerin yer aldığı ağız kısmı bulunmaktadır. Ağız kısmının ortasında ise yukarı doğru uzanan fitil işlenmiştir (F.52). 


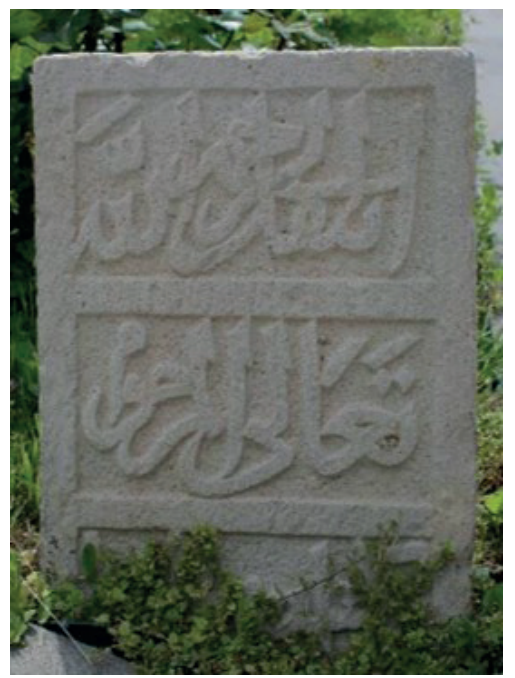

F. 51: Katalog No 35

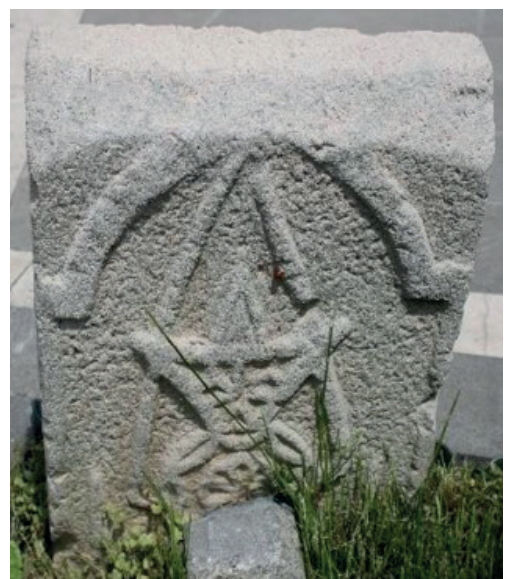

F. 52: Katalog No 35

Katalog No: 36

Bulunduğu Müze: Arkeoloji Müzesi

Müzeye Getirildiği Yer: Okul deposu

Ölçüleri (cm.): En: 16,5 Boy: 56 Kalınlık: 16,5

İşleniş Tekniği: Kabartma

Kitabesi: 


\begin{tabular}{|c|c|}
\hline $\begin{array}{c}\text { Ya Ğaffar } \\
\text { İla rahmetu'l-Lahi } \\
\text { Teâlâ... } \\
\text { Şaban... } \\
\text { Hacı Hasan } \\
\text {.......... } \\
\text { Sene... }\end{array}$ & 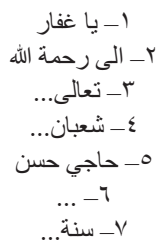 \\
\hline
\end{tabular}

Anlamı: Ey Bağışlaması bol olan Ğaffar. Şanı yüce her şeye gücü yeten Allah'ın rahmetine erişmiş... Hacı Hasan... (oğlu?) Şaban... yılında...

Tanım ve Kompozisyon: Kareye yakın prizmal kesitli ve düşey dikdörtgen gövdeye sahip olan taş, başlıklıdır. Taş, gövde ve başlık kısımlarından oluşmaktadır. Gövde üzerinde dışa doğru çıkıntı yapan bir bordür ve bordürün üzerinde ise $\mathrm{Fes}^{17}$ adı verilen bir başlık yer alır. Taşın yüzeyinde kabartma tekniğiyle işlenmiş yedi satırlık kitabe metni yer almaktadır. Satırlar birbirlerinden kartuşlarla ayrılmaktadır (F.53).

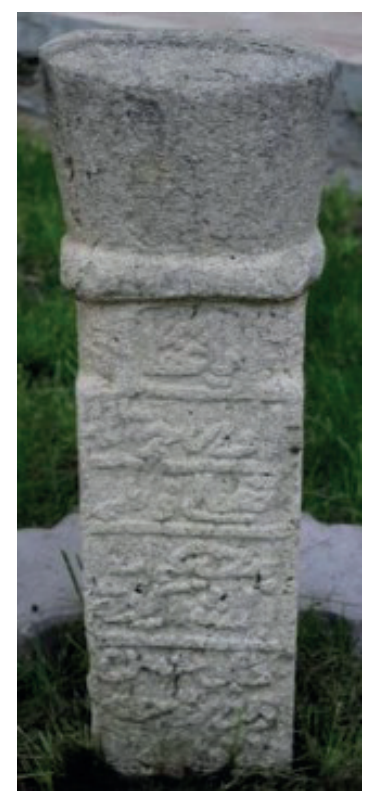

F. 53: Katalog No 36

17 Fes: Sultan II. Mahmud, Vak'a-i Hayriye'den sonra giriştiği reform hareketlerinin içine Osmanlı sarığını da değiştirme kararını kattı. 3 Mart 1829'da fes, resmi başlık olarak giyilmeye başlanıldı. İşli, a.g.e., s. 126-146. 
Katalog No: 37

Bulunduğu Müze: Etnoğrafya Müzesi

Müzeye Getirildiği Yer: Kırklar Mezarlığ 1

Ölçüleri (cm.): En: 77 Boy: 50 Kalınlık: 15,5

İşleniş Tekniği: Kabartma

Kitabesi:

Fi'l-ardi menzellezi yeşfeu'

1- إل في الارض منذا الذي يشفع

Anlamı: Yerde... onun (indinde) şefaat edebilecek... ${ }^{18}$

Tanım ve Kompozisyon: Lahit tipi mezar şeklinde düzenlenmiş olan taşın bir kenarı ayakta kalmıştır. Kalan kenar yüzeyinde Kabartma tekniğinde işlenmiş tek satırlık kitabe kuşağı yer alır. Lahtin üst kısmında basamak şeklinde düzenlenmiş geometric bir kabartma yapılmıştır. Bu motifin her iki ucunda birer tane üst yüzleri geometrik bezemeli sekizgen prizmal çıkıntılar yapılmıştır (F.54).

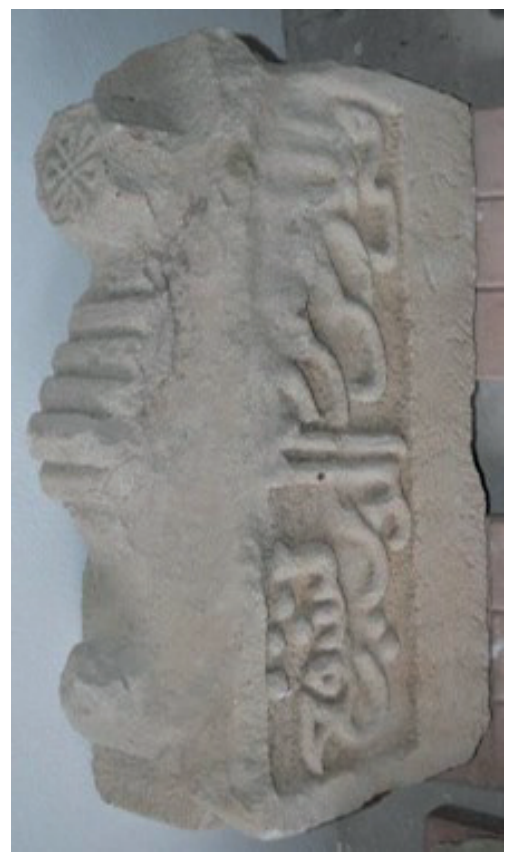

F. 54: Katalog No 37

18 Ayetel Kürsinin bir kısmı yazılıdır. Bir cümlenin sonu diğer cümlenin başı olduğu için tam bir anlam bütünlüğü olmayacaktır. 
Katalog No: 38

Bulunduğu Müze: Etnoğrafya Müzesi

Müzeye Getirildiği Yer: Kırklar Mezarlığı

Ölçüleri (cm.): En: 20 Boy: 35 Kalınlık: 6,5

İşleniş Tekniği: Kabartma

Kitabesi:

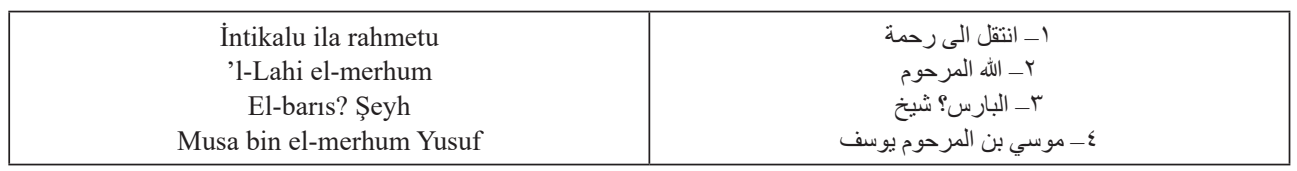

Anlamı: Allah'ın rahmetine intikal eden merhum, rahmetli Yusuf'un oğlu barış? Şeyh Musa

Tanım ve Kompozisyon: Dikdörtgen kesitli, düşey dikdörtgen gövdeye sahip olan taşın yüzeyinde dört satırlık kitabe metni bulunmaktadır. Kabartma tekniğinde işlenmiş olan satırlar birbirinlerinden kartuşlarla ayrılmıştır. Dikdörtgen şekilli işlenmiş olan kartuşlar orta kısımda birbirlerine bağlanarak devam ettirilmiştir. Kartuşlar kenarlarda dışa doğru uzatılarak sonsuzluk prensibi ile devam ediyormuş gibi bir anlayışla düzenlenmiştir (F.55).

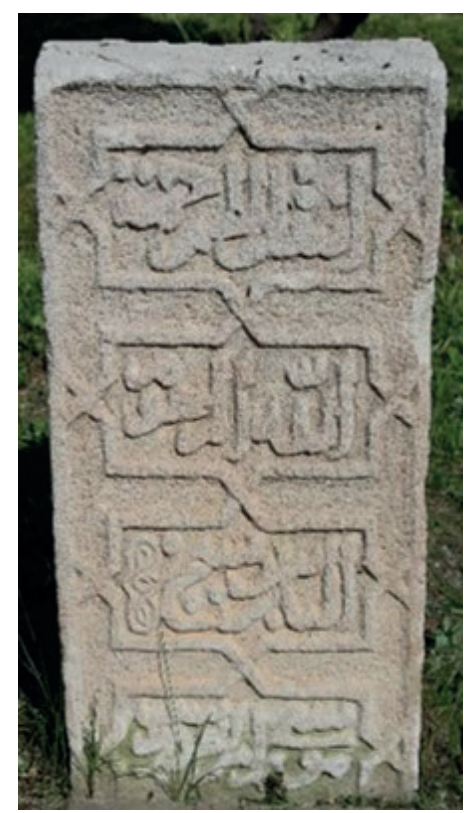

F. 55: Katalog No 38 
Katalog No: 39

Bulunduğu Müze: Arkeoloji Müzesi

Müzeye Getirildiği Yer: Kırklar Mezarlığı

Ölçüleri (cm.): En: 41,5 Boy: 42 Kalınlık: 8

İşleniş Tekniği: Kabartma

Kitabesi: Okunamadı

Tanım ve Kompozisyon: Hem üst hem de alt kısımdan kırık olan taş, dikdörtgen kesitli, düşey dikdörtgen gövdeye sahiptir. Kitabesi tamamen yıpranmış olan taşın ön yüzünde dikdörtgen bir kartuş yer alır (F.56). Kartuş orta kısımdan üst ve alt satırdaki kartuşa bağlanır şekilde dışa yansıyan kısımları ile devam ettirilmiştir. Kartuşun yan kısımlarında ise bu devam ettirme varmış gibi sonsuzluk anlayışında yapılmıştır. Taşın arka yüzünde ise ortada bir kandil motifi işlenmiştir. Kandilin her iki yanında dikdörtgen formda birbirinin devamı şeklinde yapılmış içi boş bordürler yer alır. Bordürlerden sonra her iki yanda birer şamdan ve daha sonra ise kandili asmak için işlenmiş birer ip gibi zincirler vardır. Kompozisyonun ortasında kandil yer alır. Alttan yukarıya doğru daralan bir kaide, geniş yuvarlak bir gövde ve gövdenin üzerinde ise alttan yukarıya doğru genişleyen ağzı olan kandilin gövde kısmında çiçek motifi yapılmıştır. Kandilin hem kaide hem de ağız kısmında geometrik şekiller vardır. Kaidenin her iki yanında birer yaprak motifi işlenmiştir. Kandilin gövde kısmında işlenmiş olan çiçek, kalan izlerden anlaşıldığı kadarıyla taşın alt kısmında da işlenmiştir (F.57a, F57b).

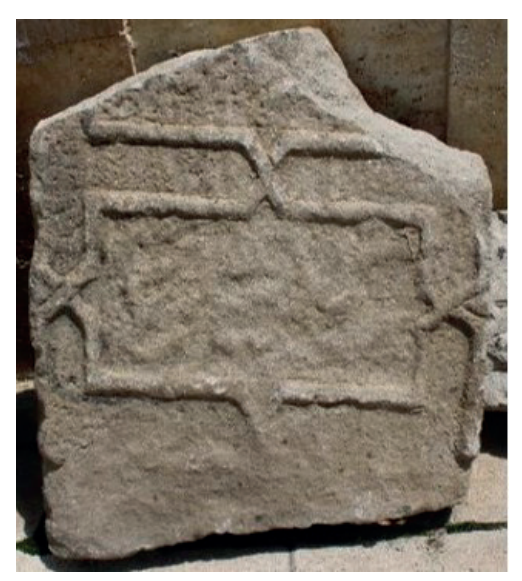

F. 56: Katalog No 39 


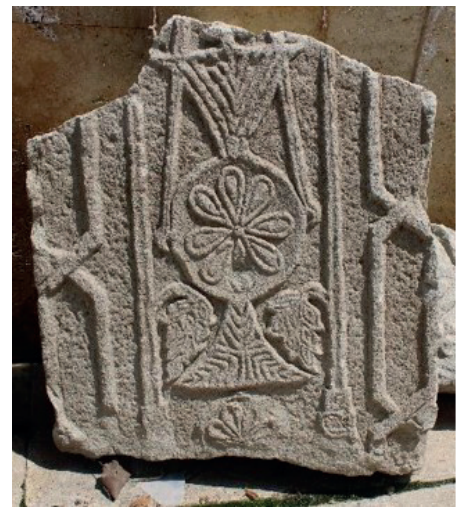

F. 57a: Katalog No 39

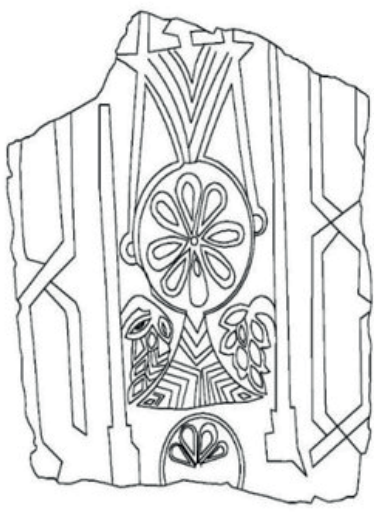

F. 57b: Katalog No 39

\section{Değerlendirme}

Bu çalışmada “Malatya Arkeoloji ve Etnoğrafya Müzeleri’nde Bulunan Türk- İslam Dönemi Mezar Taşları” incelenmiştir. Müzelerde bulunan mezar taşları; form, malzeme, teknik ve süsleme özellikleri ile sanat tarihi açısından değerlendirilmeye çalışılmıştır.

İncelenen 39 taş, baş taşıdır. Bu taşlardan 21'i sağlam, 16'sı kırılmış vaziyettedir. Bunların dışında bütün olmakla birlikte kitabeleri tamamen tahrip olan 2 şahide daha bulunmaktadır. Müzelerde bulunan taşların 6'sı kadın, 15'i erkek mezar taşıdır. 18 taşın ise kimliği belli değildir.

Değerlendirilen mezar taşlarının en erken tarihlisi 1307, en geç tarihlisi ise 1912'dir. Bu şahidelerin 2'si 14. yy. aralığına $(1347,1374)^{19}$, 2'si 15, yy. aralığına $(1432,1488-1489)^{20}$, 5'i 18. yy. aralığına $(1701,1718,1747,1792,1795)^{21}$, 4'ü 19. yy. aralığına $(1886,1888,1892)^{22}$, 5'i 20. yy. aralığına $(1903,1905,1906,1912)^{23}$ tarihlenmektedir. Mezar taşlarından 20 örnekte ${ }^{24}$ kitabeler ya kırık ya da ayet yazıldığ 1 için üzerinde tarih ibaresi yoktur. Kırklar Mezarlığı'ndan getirilen örnekler ${ }^{25}$ tarih ibaresi olan mezar taşları ile değerlendirildiğinde bu taşlarında 14. yüzyıldan olmak üzere 13. yüzyılın sonu ile 15. yüzyılın ortası arasındadır ${ }^{26}$.

İncelenen taşlarda kitabe metinlerinin bazılarında ayetten oluşan metinlerin ${ }^{27}$ yanı sıra bazı örneklerde ${ }^{28}$ de tarih kısımları rakam kullanılmadan yazıyla belirtilmiştir.

19 Katalog No: 2,3

20 Katalog No: 4, 5

21 Katalog No: 6, 7, 8, 9, 10

22 Katalog No: 11, 12, 13, 14

23 Katalog No: 15, 16, 17, 18, 19

24 Katalog No: 20, 21, 22, 23, 24, 25, 26, 27, 28, 29, 30, 31, 32, 33, 34, 35, 36, 37, 38, 39

25 Katalog No: 20, 21, 22, 23, 29, 34, 35, 39

26 Çal, a.g.m., s.65.

27 Katalog No: 21, 22, 23, 37,

28 Katalog No: 1, 3, 4, 5, 17 
Mezar taşı kitabelerinde tarih bulunması, Türk-İslam dönemi boyunca devam etmiştir ${ }^{29}$. Tarih olarak Ebcet hesabı kitabelerde sıklıkla kullanılmıştır. İbrani alfabesine dayanan ebcet hesab1, her harfe bir rakam değeri vermek suretiyle tarih düşürme anlamına gelmektedir ${ }^{30}$. Müzelerde değerlendirdiğimiz mezar taşlarından Katalog No: 19'da ebcet hesabıyla tarih belirtilmiştir.

Çalışmadaki 37 şahide yerlerinden çıkartıldığı için mezar tipilojisi tespit edilememiştir. 2 şahidenin (Katalog No: 22 ve 37) "Lahit Tipi Mezar"31 olduğu belirlenmiştir. Şahideler form bakımından dikdörtgen kesitli, düşey dikdörtgen ve kareye yakın prizmal kesitli, düşey dikdörtgen gövdeye ayrılmıştır. Kimliği belli olan şahidelerin kime ait olduğuyla beraber şekillenen başlıklari ${ }^{32}$ kadın ve erkek mezar taşlarında farklılık göstermektedir.

Kadın şahidelerin 2'si kareye yakın prizmal kesitli, düşey dikdörtgen gövdeye sahip olmasının yanı sıra Katalog No: 7'de başlık yapılmıştır. Katalog No: 8'in başlık kısmı kırık olduğu için başlığının varlığı tespit edilememiştir. Diğer kadın şahideler dikdörtgen kesitli, düşey dikdörtgen formda yapılmış olmalarına rağmen alınlık kısmında farklılık göstermektedir. Taşlardan 2'si' ỉ üģen formlu alınlıkla, 1'i (Katalog No: 34) üç dilimli alınlıkla, 1'i (Katalog No: 33) ise yalın bir dikdörtgen şekille tamamlanmıştır.

Erkek şahidelerin 5' ${ }^{34}{ }^{34}$ yalın bir dikdörtgenle sonlandırılmıştır. Taşlardan 1'i üçgen formlu alınlıkla (Katalog No: 29) tamamlanmıştır. Diğer 9 baş taşı ise kareye yakın prizmal kesitli, düşey dikdörtgen gövdeye sahiptir. Bu taşlardan 3'ünde ${ }^{35}$ başlık kullanılmıştır. 6 şahide ${ }^{36}$ de başlık tespit edilememiştir.

Müzelerde incelenen taşların ya kırık ya da kitabelerinin yıprandığı için kime ait olduğu belli olmayan şahidelerde bulunmaktadır. Kimliği belli olmayan 13 taş ${ }^{37}$ yalın bir dikdörtgen forma sahiptir. Taşlardan 1'i üçgen formlu (Katalog No: 20) alınlıkla, 1'i ise üçgen dilimli (Katalog No: 23) olarak tamamlanmıştır. İncelenen taşlar arasında 2 adet lahit tipi (Katalog No: 22, 27) taşın kimliği belli değildir.

29 Abdulhamit Tüfekçioğlu, "Türk- İslam Dönemi Türbe ve Mezar Taşı Kitabelerinde Tarih İbareleri", Geçmişten Günümüze Mezarlık Külttürü ve İnsan Hayatına Etkileri Sempozyumu, İstanbul, 1999, s.401.

30 Selahattin Erker, "Kitabelerde (Ebcet) Hesabının Rolü", Vakıflar Dergisi, C.3, Ankara, 1996, s. 17.; İsmail Yakıt, "Vefat Tarihlerinde Ebced ve Anlam Sanatı", Geçmişten Günümüze Mezarlık Kültürü ve İnsan Hayatına Etkileri Sempozyumu, İstanbul, 1999, s.405-417.

31 Çal, a.g.m., s.69.

32 Halit Çal, "İstanbul Eyüp’teki Erkek Mezar Taşlarında Başlıklar", Tarihi, Kültürü ve Sanatıyla III. Eyüpsultan Sempozyumu Tebliğler (28-30 Mayıs), İstanbul, 2000, s. 206-255.; Hans Peter Laqueur, Hüve'l Baki, İstanbul'da Osmanlı Mezarlıkları ve Mezar Taşları, Tarih Vakfı Yurt Yayınları, İstanbul, 1997, s. 138-140.; İşli, a.g.e., s.56-115.

33 Katalog No: 6, 18

34 Katalog No: 16, 25, 30, 36, 38

35 Katalog No: 9, 10, 12

36 Katalog No: 13, 14, 15, 17, 19, 32

37 Katalog No: 1, 2, 3, 4, 5, 21, 24, 26, 27, 28, 31, 35, 39 
Tarihin en eski medeniyetinden günümüze kadar mezar taşları ve kitabeleri, toplumların yaşamları ile ilgili en somut ve en güvenilir belgeleri sunması bakımından önem taşımaktadır ${ }^{38}$.

Anadolu mezar taşlarında yazı, belge niteliği taşımasının yanı sıra süsleme unsuru olarakta kullanılmaktadır. En çok kullanılan yazı tipleri arasında Kufi, sülüs ve nesih yazı türleri gelmektedir $^{39}$. İncelediğimiz mezar taşlarında ise yazı tipi olarak sülüs ${ }^{40}$, talik ${ }^{41}$ ve kufi $^{42}$ kullanılmıştır.

Genel olarak Anadolu mezar taşları üzerinde yer alan kitabelerde Kur'an'dan ya da hadislerden alınmış dini içerikli metinlerin, çeşitli güzel sözlerin ve şiirlerin yanı sıra mezarda yatan kişiyle ilgili bilgilerde yer almaktadır³ ${ }^{43}$.

Mezar taşı kitabelerindeki konular; yakarış ya da başlangıç, dua, kimlik, dua İsteme,tarih olmak üzere beşe ayrılmaktadır ${ }^{44}$. İncelediğimiz örneklerden yakarış veya başlangıç ifadesi olarak 1'inde (Katalog No: 2) "Ya Hallak", 1'inde (Katalog No: 10) "Ya Baki", 9'unda45 "Ya Gaffar", 1'inde "Ya Settar" (Katalog No: 19), 1'inde "Ente'l Baki” (Katalog No: 28), 1'inde “Allah" (Katalog No: 29), 1'inde "Es-Samed” (Katalog No: 31) yazılıdır.

Dua ifadesi olarak erkek mezar taşlarında 7'sinde 46 “merhumu'l mağfur", 1 'inde "merhum ve mağfur" (Katalog No: 12), 2'sinde 47 "merhum", 1'inde “el-merhumu'l mağfur" (Katalog No: 9), 1'inde (Katalog No:19) “el-merhumu'l mağfuru'l yer alır. Kadın mezar taşlarında ise 3'ünde 48 "merhume'l mağfure”, 1'inde (Katalog No: 18) "el-merhumu'l mağfur", 1'inde (Katalog No: 8) "merhumetu'l mağfure" işlenmiştir. Taşlardan kimliği belli olmayanlarda ise 2'sinde 49 “merhum", 1'inde (Katalog No: 35) ise "el merhum” ifadesi yazılmıştır.

Mezar taşlarında kalıp şeklinde yazılan duaların yanı sıra meslek belirleyici unsurlarda yer alır. İncelediğimiz mezar taşlarında "nazır (bakan veya idareci), hafiz" ${ }^{50}$ meslekleri dikkat çekmektedir.

Bunların yanı sıra birçok erkek ve kadın mezar taşlarında çeşitli lakaplar ve ünvanlar da kullanılmıştır. Erkek mezar taşlarında 3'ünde ${ }^{51}$ "A ğa", 5'inde ${ }^{52}$ "Hacı", 1 'inde (Katalog No: 25) “Bey", 2'sinde 53 "Efendi", 1'inde (Katalog No: 29) "Emir", 1'inde (Katalog No: 38)

38 Sahure Yariş, Üsküdar'daki Bir Grup Cami ve Hazirelerindeki Mezar Taşları, Atatürk Üniversitesi Sosyal Bilimler Enstitüsü Sanat Tarihi Anabilim Dalı, (Yayınlanmamış Doktora Tezi), Erzurum, 2015, s.338.

39 Uğur Derman, "Mezar Kitabelerinde Yazı Sanatımız", Turing Otomobil Kurumu Belleteni, S.49\328, İstanbul, 1975, s.37-38.

40 Katalog No: 1, 2, 3, 4, 5, 16, 20, 21, 22, 24, 25, 26, 28, 29, 30, 31, 33, 34, 35, 37, 38

41 Katalog No: 6, 7, 8, 9, 10, 11, 12, 13, 14, 15, 17, 18, 19, 27, 32, 36

42 Katalog No: 23

43 Ertan Daş- Şakir Çakmak, Karşıyaka'nın Taş Çiçekleri, Yetişkin Kültür Yayımlar, İzmir, 2013, s.269.

44 Laqueur, a.g.e., s.80.

45 Katalog No: 6, 7, 8, 11, 12, 14, 19, 30, 36

46 Katalog No: $12,13,14,15,16,17,29$

47 Kotolog No: 30, 38

48 Katalog No: 6, 7, 33

49 Katalog No: 4, 28

50 Katalog No: 13, 25

51 Katalog No: 9, 15, 16

52 Katalog No: 9, 14, 17, 30, 36

53 Katalog No: 15, 19 
“Şeyh” ünvanları kullanılmıştır. Kadın mezar taşlarında ise 2 örnekte ${ }^{54}$ "Hatun”, kimliği belli olmayan 1 örnekte (Katalog No: 12) ise "Hacı" ünvanı yazılmıştır.

Bunların dışında bazı erkek ve kadın mezar taşlarında akrabalık bağlarını gösteren "oğlu, kızı, kerimesi, annesi” gibi isimler yer almıştır"s . "Soy” manasında ise "Öksüzoğlu Zade, Bekerdi Zade, Nesuni Zade" lakapları geçmektedir ${ }^{56}$.

Değerlendirilen örneklerde sıkça kullanılan erkek ve kadın isimleri vardır. Erkek isimleri "Hüseyin, Osman, Hasan, Şemseddin, Mahmud, Muhammed, Mustafa, Yakup, Sami, Yusuf, İsmail, Musa" isimleridir" ${ }^{57}$ Kadın ismi olarak da "Amine ve Hatice"58 isimleri yazılıdır.

İncelediğimiz mezar taşlarından çoğunda ölen için dua istendiği çeşitli Fatiha ibarelerinden anlaşılmaktadır. 2'sinde 59 "Ruhuna el-Fatiha", 2'sinde 60 "Ruhu İçün Fatiha", 1'inde (Katalog No: 14) "Ruhu için Fatiha", 2'sinde ${ }^{61}$ "Ruhuna Fatiha" ifadeleri yazılıdır.

Mezarda yatan kişi hakkında önemli bilgilerin edinildiği unsurlardan biri de başlıklardır. Dönemlerine göre farklılık gösteren başlıklardan ölen kişinin mesleği, sosyal sınıfı hakkında bilgi alınabilir' ${ }^{62}$. Başlıkların mezar taşlarında kullanılmaya başlanması, Orta Asya Türk kültüründeki balbal geleneğine kadar inmektedir ${ }^{63}$. Selçuklu ve Beylikler Döneminde de görülen başlıklı mezar taşları Osmanlıda zenginleşerek devam etmiştir. Ölen kişinin kimliğini belirten önemli bir sembol haline gelmiştir ${ }^{64}$.

İncelenen mezar taşlarından 7 adedinde başlık tespit edilmiştir. Bu başlıklardan ilki "Kalpak" tır. 3 adet mezar taşında Kalpak kullanılmıştır. Bu taşlardan Katalog No: 7 kadın, diğer 2'si ise erkek ${ }^{65}$ mezar taşıdır. Kalpak (Şubara), Yeniçeri teşkilatına mensup dünyanın ilk havan topu yapan sınıfı olan ${ }^{66}$ Humbaracılar tarafından normal zamanda takılan bir başlık türüdür. Humbaracıların derecelerine göre rengi kırmızı, beyaz ve keçe renginde olan bu başlık, çuhadan yapılmış, boru gibi uzun bir şekle sahiptir ${ }^{67}$.

54 Katalog No: 33,34

55 Katalog No: 6, 7, 8, 9, 10, 12, 15, 16, 18, 19, 29, 30, 32, 33, 36, 38

56 Katalog No: 16, 18, 19

57 Katalog No: 6, 7, 9, 10, 12, 13, 15, 16, 17, 19, 25, 29, 30, 32, 33, 36, 38

58 Katalog No: 8, 18, 33

59 Katalog No: 15,32

60 Katalog No: 8, 18

61 Katalog No: 9, 10

62 Çal, a.g.m., s.206-225.; Şerife Tali, “Kayseri/Gesi Mezarlığı Mezar Taşları Üzerine Bir Deneme”, Atatürk Üniversitesi Türkiyat Araştırmaları Enstitüsü Dergisi, S.49, Erzurum, 2013, s. 387.

63 Oktay Belli, “Türkler'de Taş Heykeller ve Balballar”, Türkler Ansiklopedisi, C.3, Ankara, 2002, s. 910.; Esat Karkmaz, Eski Türk İnançları ve Şamanizm Terimleri Sözlüğü, Anahtar Kitaplar Yayınları, İstanbul, 2003, s. 36.; Daş, a.g.e., s. 17.

64 Celal Esat Arseven, Türk Sanat Tarihi, MEB Yayınları, İstanbul, 1954, s. 45.; Nebi Bozkurt, "Mezarlık” mad., TDV İslam Ansiklopedisi, C. 29, s.520-521.

65 Katalog No: 10, 12

66 İ. Hakkı Uzunçarşı1lı, Osmanlı Devleti’nin Kuruluşundan İstanbul'un Fethine Kadar, C.1, Türk Tarih Kurumu Yayınları, İstanbul, 2015, s.507-518.

67 İşli, a.g.e., s. 138 
Taşlarda kullanılmış diğer başlık türü “Çatal Kalafat” tır. İncelenen ve erkek mezar taşı olan 2 örnekte ${ }^{68}$ bu başlık türü kullanılmıştır. Kapıkulu askerlerinden Kıt'a Kumandanları tarafından takılan başlık türüdür. Başa giren kısmı yukarıya doğru ters huni çanağı gibi açılan ve tepesi dairesel düz, terksiz, düğümsüz bir başlık olan Çatal Kalafat; 1698-1699'dan 1826 yılına kadar kullanılmıştır ${ }^{69}$.

"Dolama" kullanılan başlık türlerinden bir diğeridir. Erkek mezar taşı olan Katalog No: 9'da yapılmıştır. Hasodalılar'ın kullandıkları bir başlık türü olan Dolama, kavuk etrafına kıvrılmış bezin sarılması suretiyle meydana gelmektedir ${ }^{70}$.

İncelenen örneklerde dikkat çeken diğer başlık türü "Fes" dir. Erkek mezar taşı olan Katalog No: 36 fes ile tamamlanmıştır. Sultan II. Mahmut Vak'a-i Hayri-ye'den sonra yaptığı reform hareketleri içerisinde Osmanlı sarığıda yer vermiştir. 3 Mart 1829 tarihinde sarık değiştirilerek "Fes" giyilmeye başlandı. Fesin üzerine konulan püskül ve şal örtüler II. Mahmut ve Sultan Abdülmecid devrinde derece belirlemede önemli bir unsur olmuşlardır. Üst düzey devlet memurlarının feslerin kenarlarına sırma şeritler konularak dereceleri vurgulanmıştır ${ }^{71}$.

İncelediğimiz mezar taşlarındaki motifler; yapılmış oldukları dönemlerin sanat anlayışını, sosyal ve kültürel etkileşimleri vb. unsurları yansıtmaları açısından önemlidir. Katalogda değerlendirilen 39 örnekte, süsleme açısından bitkisel, nesneli ve geometrik motifler bulunmaktadır.

İslamiyet'in figüratif açıdan resim ve heykel dalındaki bazı kısıtlamaları sonucunda yalnızca cansız olan şeylerin resminin yapılmasına izin verilmiştir. Bitkiler bu sınıfın içinde yer almıştır ${ }^{72}$. Bu nedenle mezar taşı süslemesinde bitkiler yoğun olarak işlenmiştir. Selçuklu dönemi mezar taşlarında realist bitkiler geniş yer tutarken, Osmanlılarda realist bitki süslemeleri, Batılılaşma ile birlikte en gelişmiş şeklini kavuşmuştur ${ }^{73}$. Türk sanatında 1703-1739 yılları arasında yaşanan Lale Devri ve 1839 Tanzimat Fermanından sonra batı etkisinin hem ekomomik ve sosyal yaşamda hem de sanat alanında farklılıkların yaşanmasına sebep olmuştur ${ }^{74}$.

Değerlendirdiğimiz örneklerde stilize çiçek ve yaprak motiflerinin yanı sıra iç içe girmiş bitkisel motiflerde dikkat çekmektedir" ${ }^{75}$. Mezar taşlarının arka yüzlerinde "S" ve "C" kıvrımlarından oluşan barok motifler ${ }^{76}$ sıklıkla kullanılmıştır. Bu motifler sarmaşık şeklinde

68 Katalog No: 2, 13

69 İşli, a.g.e., s. 126

70 İşli, a.g.e., s. 36.

71 İşli, a.g.e., s. 148-149.

72 Hans Peter Laqueur, Hüve'l-Bâki İstanbul'da Osmanlı Mezarlıkları ve Mezar Taşları, (Çev.: Selahattin Dilidüzgün), İstanbul, 1997, s.129-130.

73 Hans Peter Laqueur, "Osmanlı Mezar Taşlarının Süslemesinde Bitkisel Motifler", Suud Kemal Yetkin'e Armağan, Hacettepe Üniversitesi Armağan Dizisi:1, Ankara, 1984, s. 263.; Alev Çakmakoğlu Kuru, "Orta Asya Türk Sanatında Palmet ve Lale Motiflerinin Değerlendirilmesi Hakkında Bir Deneme", Belleten, C.61, 1997, s. 4-37.

74 Semavi Eyice, “XVIII. Yüzyılda Türk Sanatı ve Türk Mimarisinde Avrupa Neo Klasik Üslubu”, Sanat Tarihi Yıllığı, S.9-10, İstanbul, 1981, s. 163-190.

75 Katalog No: 3, 20, 23, 25, 26, 27, 30, 31, 33, 39.

76 Gül Tuncel, "Üsküp Alaca Camii Haziresindeki Şahideler”, Hacettepe Üniversitesi Edebiyat Fakültesi Dergisi, C.22, S.1, Ankara, 2005, s.215-236. 
taşların yüzeylerinde işlenmiştir. Katalog No:3'te taşın arka yüzeyine işlenmiş olan kandilin üst kısmında ve kandilin her iki yanında yapılmış yaprak motifleri vardır. Katalog No: 39' da ise yine bir kandil motifi işlenmiştir. Kandilin gövde kısmında ortada yapılmış olan çok yapraklı bir çiçek motifi bulunmaktadır. Süslemeler kitabe metinlerinin çevresini süslemek içinde kullanılmıştır. Katalog No: 23 'te ortada kitabe metni, metnin her iki yanında ise "S" ve "C" kıvrımlarıyla yapılmış sarmaşıklar işlenmiştir. Katalog No: 31 'de ise kitabenin son satırında yaprak motifi işlenerek kitabe tamamlanmıştır. Bitkisel süslemelerde taşın arka yüzeyinin tamamının süslendiği diğer bir örnek Katalog No: 27'dir. Üzüm yapraklarının işlendiği taşın yüzeyinde birbirini tekrarlar durumda işlenmiş yapraklar vardır. Bereket ve ölümsüzlüğün sembolü olan üzüm yerini yapraklara bırakmıştır. Yapraklar sarmaşık şeklinde taşın yüzeyini kaplamıştır. Anadolu'da üzüm ve bağcılık, Türklerin erken dönemden beri bildikleri bir kültürdür. Bolluğu, bereketi ve doğurganlığg sembolize eden üzüm, Türkçe bir kelimedir ve yazılı belgelerde ilk kez Uygur'larda karşımıza çıkmaktadır ${ }^{77}$.

Süslemelerde kullanılan diğer bir bitkisel motif palmettir. İncelenen 3 örnekte ${ }^{78}$ palmet işlenmiştir. El pencesine benzerliği ${ }^{79}$ ile dikkat çeken palmet motiflerinin erken örnekleri, M. Ö. I. binde Akdeniz çevresinde oluşan kültürde de yaygınlaşmıştır ${ }^{80}$. Bu motif, Klasik Yunan sanatından sonra Helenistik dönemde de işlenen motiflerden olmuştur ${ }^{81}$. Değerlendirilen örneklerde palmet Katalog No: 1 ve 3 'te kandili asmak için yapılmış zincirlerin her iki kenarında süsleme amacıyla işlenmiştir. Katalog No: 33 'te ise taşın arka zemininde stilize çiçek ve yaprak motifleri arasında motifleri bağlayıcı bir unsur olarak yapılmıştır.

Mezar taşlarında dikkat çeken diğer bir süsleme çeşidi geometrik motiflerdir. Müzelerde bulunan 6 örnekte ${ }^{82}$ geometrik süslemeler vardır. Süslemeler baklava dilimi, üçgenler veya zincir şeklinde işlenerek uygulanmışlardır. Motifler genellikle ya kitabe çevresinde geometrik şeritler olarak ya da başka bir süsleme çeşidinin etrafına işlenip, o motifi sınırlamak için kullanılmışlardır. Kainatın sembolleri olarak tanımlanan geometrik şekiller Anadolu'da daha çok Selçuklular döneminde görülmektedir. Bu motifler İslam sanatında sonsuzluk ve sürekliliği göstererek Allah`1 hatırlatması bakımından önem taşımaktadır. Gücün, adaletin, genişliğin ve sonsuzluğun sembolü olan geometrik çizgiler (tek ve sonsuz olan), bir düzen içerisinde yerleştirilirler ${ }^{83}$. Geometrik

77 Bahaeddin Ögel, Türk Kültür Tarihine Giriș, C. 2, Türk Tarih Kurumu Yayınları, Ankara, 2000, s.325-330.; R. Eser Gültekin, "Türklerde Bereket Sembolü Olarak Kullanılan Meyve Motifleri ve Mimaride Değerlendirilmesi”, Turkish Studies, C.3, S.5, Ankara, 2008, s.12-13.

78 Katalog No: 1, 3, 33

79 Celal Esad Arseven, "Palmet”, Sanat Ansiklopedisi, C. IV, İstanbul, 1994, s. 1587.; Metin Sözen-Uğur Tanyeli, Sanat Kavramları ve Terimleri Sözlüğü, Remzi Kitabevi, İstanbul, 2005, s. 184.

80 Cevat Başaran, “Anadolu Roma Çağı Lotus-Palmet Örgesinde Tip Gelişimi”, Türk Arkeoloji Dergisi, S. 28, Ankara, 1989, s. 53-72.

81 Hamza Gündoğdu, “İkonografik Açıdan Türk Sanatında Rûmî ve Palmetler”, Sanat Tarihinde İkonografik Araştırmalar, Ankara, 1993, s. 199-201.

82 Katalog No: 2, 22, 24, 25, 30, 35

83 Hüseyin Kutlu, Kaybolan Medeniyetimiz Hekimoğlu Ali Paşa Camii Haziresi ‘ndeki Tarihi Mezar Taşları, Biksad Yayınevi, İstanbul, 2005, s.30. 
motiflerden taşlar üzerinde sıklıkla kullanılanlardan biri çarkıfelektir. Çarkıfelek motifi, Orta Asya'da, bugünkü Moğolistan'ın kuzey sınırlarından İran'a ve Anadolu'ya kadar çeşitli kültürleri kapsayan geniş bir coğrafyada görülmektedir. Çarkıfelek, bir dönem Budizm'in ve daha sonra İslami geleneklerle anlamı değişikliğe uğramış bir sembol haline gelmiştir ${ }^{84}$.

Türk Sanat Tarihi içerisinde her alanda sıkça görülebilen, dünyanın gelip geçiciliğini simgeleyen $^{85}$, ölüye şefaat ve onu ölümsüzleştirme amacıyla işlenen ${ }^{86}$ çarkıfelek motifi, katalogda 3 örnekte ${ }^{87}$ işlenmiştir. Dairesel yay kollarının bir merkezi odak almasıyla oluşan çarkıfeleğin mezar taşlarında süsleme unsuru olarak kullanılması, İslam sanatındaki sembolik içeriğiyle ilişkisi, gelinen noktaya geri dönüş algılanmasıyla ölümle bağlantı kurulabilir ${ }^{88}$.

İncelenen örneklerde işlenmiş olan diğer bir süsleme ise kandil ve şamdan motifleridir. 7 örnekte ${ }^{89}$ uygulanan motifler genellikle beraber işlenmiştir. Taşın orta kısmında bir kandil ve kandilin her iki yanında birer şamdan motifiyle kompozisyon tamamlanmıştır. Kandiller genellikle alttan yukarıya doğru daralan bir kaide üzerine oturmaktadır. Ortada geniş bir gövde, gövdenin üzerinde yukarıya doğru genişleyen ağız kısmı yapılmıştır. Ağız kısmında ise yukarıya doğru daralan bir fitil işlenerek kandil sonlandırılmıştır. Şamdan motifleri ise alttan yukarıya doğru genişleyen bir kaide üzerine oturtulmuştur. Alttan yukarıya doğru daralan şamdanlar üst kısımda ya sade bırakılmış ya da birer çarkıfelek motifiyle tamamlanmışlardır. Değerlendirilen örneklerden tarihi belli olan taşların ${ }^{90}$, Erken Osmanlı döneminde yapılmış olması o döneme ait insanların duygu, düşünce ve estetik zevkine birer örnek olması açısından önem taşımaktadır.

Kandil, bir yakıtla fitil içeren ve aydınlatmada kullanılan, toprak, teneke ya da cam kaptır. İlk kandillerin muhtemelen dini mekanların içini aydınlatmak, ya da ayinlerde kullanılmak amacıyla yapılmıştır. Kandil motifinin süsleme unsuru olarak kullanımı, Bizans litürjisinde ve İslam doktrininde ilahi 1şık kavramına verilen önemden kaynaklanmaktadır ${ }^{91}$.

Aydınlatma aracı olan şamdan, geçmişten günümüze kullanılan, çeşitli boy ve ölçülerde ele alınan, bazen sade yapılan, bazen motiflerle süslenmiş nesnelerden biridir. Işı̆̆ı, nuru ifade eden, kelime anlamı 1şık olan şema kelimesinden meydana gelmektedir. Dini ve sivil mimari birimleri içerisinde bir aydınlatma aracı olarak, genellikle bakır, pirinç ya da bronz türü metallerden yapılmış şamdanlar, genellikle üzerine bir mumluk konulmuş biçimde ya da bir figür şeklinde yapılabilmiştir².

84 Ertan Daş, "Mezar Taşlarında Svastika ve Çarkıfelek Sembollerinin Kökeni ve Anlamı”, I. Uluslararası Türkİslam Mezar Taşıları Kongresi, Aydın, 2018, s. 200.

85 Aslı Sağıroğlu Aslan, Kayseri Zamantı Irmağı Çevresindeki Bezemeli Mezar Taşları, Kayseri Büyükşehir Belediyesi Kültür Yayınları, Kayseri, 2005, s. 396.

86 Beyhan Karamağaralı, Ahlat Mezartaşları, Kültür Bakanlığı Yayınları, Ankara, 1992, s. 19.

87 Katalog No: 21, 29, 34

88 Gülsen Baş, "Mardin“de Türk Dönemine Ait Bilinmeyen Bir Mezar ve Mezar Taşları", Bilig, S.61, Ankara, 2012, s. 34-35.

89 Katalog No: 1, 3, 21, 29, 34, 35, 39

90 Katalog No: 1, 3

91 Sümer Atasoy, İstanbul Arkeoloji Müzelerindeki Bronz Kandiller Katalogu, İstanbul, 1972, s. 1-3.

92 H. Kâmil Biçici, "İznik Müzesindeki Kandil ve Şamdan Motifli Mezar Taşları”, Turkish Studies, C.7, S.3, Ankara, 2012, s. 640. 
Kandil ve şamdan motifleri işlenirken yanında geometrik, sembolik veya yazı gibi öğelerde kullanılmıştır ${ }^{93}$. Katalogda yer alan 1, 3 ve 39 numaralı taşlarda bitkisel motiflerle beraber işlenmiştir. 21 ve 34 numaralı taşlarda ise geometrik motifler dikkat çekmektedir.

Müzelerdeki dikkat çeken diğer bir süsleme unsuru "Hamâ̂l” dir. Erkek mezar taş1 olan Katalog No: 14'te hamaîl işlenmiştir. Hamaîl, boyundan aşağı doğru asılan, üç veya daha fazla köşesi olan, ayetler yazılı nazarlık, muskadır ${ }^{94}$. Muska, içinde dini ve büyüleyici bir gücün saklı olduğu sanılan, taşıyanı, takanı veya sahip olanı zararlı etkilerden koruyup iyilik getirdiğine inanılan bir nesne yazılı kağıt, hamaîl (hamayıl) karşılığ kullanılmaktadır ${ }^{95}$. Mezar taşında işlenmiş olması, mezarda yatan kişiyi zararlı etkenlerden koruması amaçlanmıştır.

\section{Sonuç}

“Malatya Arkeoloji ve Etnoğrafya Müzeleri’nde Bulunan Türk- İslam Dönemi Mezar Taşları" isimli çalışmada 39 mezar taşı incelenmiştir. Bu mezar taşlarına bakıldığında genel olarak 14. yy.'ın başından 20. yy.'ın başına kadar geniş bir zaman dilimine ait oldukları görülmektedir. Müzelerde yer alan mezar taşlarından 6'sı kadın, 15'i erkeklere aittir. 18 taşın ise kimliği belli değildir.

Taşlar form olarakta sınıflandırılmıştır. Erkek mezar taşları; dikdörtgen kesitli ve düşey dikdörtgen (6 örnek), kareye yakın prizmal kesitli ve düşey dikdörtgen gövdeli (9 örnek) olarak tasnif edilmiştir. Kareye yakın prizmal kesitli ve düşey dikdörtgen gövdeli olan taşların bir kısmında başlık yapılmışken bir kısmının üst bölümü kırık olduğu için başlık olup olmadığ 1 tesbit edilememiştir. Dikdörtgen kesitli ve düşey dikdörtgen gövdeye sahip taşların bir kısmı üst bölümde üçgen formda tamamlanmasıyla farklılık göstermektedir. Kadın mezar taşları; dikdörtgen kesitli ve düşey dikdörtgen (4 örnek), kareye yakın prizmal kesitli ve düşey dikdörtgen gövdelidir (2 örnek). Kareye yakın prizmal kesitli ve düşey dikdörtgen gövdeli olan taşlardan birinin üst bölümü kırılmış, diğerinde ise başlık yapılmıştır. Dikdörtgen kesitli ve düşey dikdörtgen gövdeli taşların ise bir kısmının üst bölümü üçgen formlu, bir kısımın ise üçgen dilimli formda tamamlanmıştır. Kimliği belli olmayan taşlar dikdörtgen kesitli ve düşey dikdörtgen (16 örnek) gövdelidir. Bu taşlardan 2 örnek ise lahit tipi mezar formunda yapılmıştır.

Değerlendirilen taşlarda başlık formlarıda çeşitlilik göstermektedir. 7 örnekte dört farklı çeşit başlık tespit edilmiştir. Bunlar; dolama, kalpak, çatal kalafat ve fesdir.

Kültür varlıklarımızın korunması ve geleceğe aktarılması, her zaman dikkat edilmesi gereken

93 Selda Kalfazade- Özkan Ertuğrul, "Kandil ve Kandilin Motif Olarak Anadolu Türk Sanatındaki Kullanımı Üzerine”, Sanat Tarihi Araştırmaları Dergisi, C.2, S.5, İstanbul, 1989, s. 25.

94 M. Fahrettin Kırzıoğlu, “Khazarlar'ın Kazak ve Borçalı Boylarından Oluşan Karapapaklar'da İnsan Heykelli Kabirtaşları Yapma Geleneği”, İslam Dünyasında Mezarlıklar ve Defin Gelenekleri, C.1, Ankara, 1996, s. 297.

95 Yılmaz Yeşil, "Muskanın Tarihsel ve İşlevsel Açıdan Değerlendirilmesi ve Bu Bağlamda Zeyneddin Baba Örneklemi”, Türk Bilig, S.30, 2015, s. 51. 
konular arasında olmuştur ${ }^{96}$. Bu varlıklar içerisinde mezar taşları önemli bir yer tutmaktadır. Kitabeleri ile o dönemin sosyo-kültürel yapısının belirtilmesinde başvurulan kaynaklar arasında mezar taşları özellikle yer alırlar. Taşların yüzeyindeki kitabe metinleri yatan kişi hakkında bibliyografik bilgi vermesi bakımından önemlidirler. İncelenen mezar taşlarından 21'inde sülüs, 16'sında ta'lik, 1'inde ise kufi yazı çeşidi kullanılmıştır.

Mezar taşlarında yoğun olarak kullanılan ikonografik anlamların yüklendiği dini içerikli motifler (kandil, şamdan, çarkıfelek, hamail, palmet, üzüm yaprăğ ) değerlendirilen taşlarda işlenmiştir.

Kültürel, sosyal ve dini doku hakkındaki bilgiler edindiğimiz mezar taşları, halk kültürümüz açısından önem taşımakla birlikte bulundukları bölgelerdeki aidiyetimizi temsil etmeleri açısından da son derece önemlidir.

Teşekkür: Bu çalışmada tüm yardımları için eşim Zülküf Yariş’a, Malatya Arkeoloji ve Etnoğrafya Müzesi çalışanlarına ve kitabelerin okunmasında katkıları için Tarih Öğretmeni Abdullah Alp'a teşekkür ederim.

Acknowledgement: I would like to thank my husband Zülküf Yariş, Malatya Archeology and Ethnography Museums staff for all their help and History Teacher Abdullah Alp for his contribution to reading the inscriptions.

Hakem Değerlendirmesi: Dış bağımsız.

Çıkar Çatışması: Yazar çıkar çatışması bildirmemiştir.

Finansal Destek: Yazar bu çalışma için finansal destek almadığını beyan etmiştir.

Peer-review: Externally peer-reviewed.

Conflict of Interest: The author has no conflict of interest to declare.

Grant Support: The author declared that this study has received no financial support.

\section{Kaynakça/References}

Arseven, Celal Esad, "Palmet”, Sanat Ansiklopedisi, C. IV, İstanbul, 1994, s. 1587.

Arseven, Celal Esat, Türk Sanat Tarihi, MEB Yayınları İstanbul, 1954.

Aslan, Aslı Sağırığlu, Kayseri Zamantı Irmağı Çevresindeki Bezemeli Mezar Taşları, Kayseri Büyükşehir Belediyesi Kültür Yayınları, Kayseri, 2005.

Atasoy, Sümer, İstanbul Arkeoloji Müzelerindeki Bronz Kandiller Katalogu, İstanbul, 1972.

Bacque, Jean- Louis, "Osmanlı Mezarlıklarının İncelenmesi: Yöntemler ve Geleceğe Dönük Düşünceler”, İslam Dünyasında Mezarlıklar ve Defin Gelenekleri I, Ankara, 1996, s. 135-158.

Baş, Gülsen, "Mardin'de Türk Dönemine Ait Bilinmeyen Bir Mezar ve Mezar Taşları", Bilig, S.61, Ankara, 2012, s. 31-46.

Başaran, Cevat, “Anadolu Roma Çağı Lotus-Palmet Örgesinde Tip Gelişimi”, Türk Arkeoloji Dergisi, S. 28, Ankara, 1989, s. 53-72.

Belli, Oktay, “Türkler'de Taş Heykeller ve Balballar”, Türkler Ansiklopedisi, C.3, Ankara, 2002, s. 910-914.

Biçici, H. Kâmil, “İznik Müzesindeki Kandil ve Şamdan Motifli Mezar Taşları”, Turkish Studies, C.7, S.3, Ankara, 2012, s. 637-661.

96 Baş, a.g.m., s.37. 
Biçici, H. Kamil, “Tire Müzesi’nde Bulunan Süslemeli Mezar Taşlarından Bazı Örnekler (XVIII-XX. yy.)”, Ankara Üniversitesi İlahiyat Fakültesi Dergisi, S.50, Ankara, 2009, s.109-150.

Bozkur, Nebi t, "Mezarlık” mad., TDV İslam Ansiklopedisi, C. 29, 2004, s.519-522.

Çal, Halit, “İstanbul Eyüp’teki Erkek Mezar Taşlarında Başlıklar”, Tarihi, Kültürü ve Sanatıyla III. Eyüpsultan

Sempozyumu Tebliğler (28-30 Mayıs), İstanbul, 2000, s. 206-255.

Çal, Halit, "Malatya Kırklar Mezarlığındaki Mezar- Mezar Taşı Tipleri”, Milli Folklor Dergisi, S. 115, 2017, s. 63-78.

Daş, Ertan - Çakmak, Şakir, Karşıyaka'nın Taş Çiçekleri, Yetişkin Kültür Yayımlar, İzmir, 2013.

Daş, Ertan, "Mezar Taşlarında Svastika ve Çarkıfelek Sembollerinin Kökeni ve Anlamı”, I. Uluslararası

Türk- İslam Mezar Taşıları Kongresi, Aydın, 2018, s. 199-206.

Daş, Ertan, İzmire’de Taş Çiçekler (Kemeraltı Hazirelerindeki Mezar Taşları), İzmir Büyükşehir Belediyesi Kent Kitaplığ̀, İzmir, 2012.

Derman, Uğur, "Mezar Kitabelerinde Yazı Sanatımız”, Turing Otomobil Kurumu Belleteni, S.49\328, İstanbul, 1975, s.36-47.

Erker, Selahattin, "Kitabelerde (Ebcet) Hesabının Rolü", Vakıflar Dergisi, C.3, Ankara, 1996, s.17-26.

Ertaş, Zafer, “Antalya Bölgesi Bir Grup Mezar Taşı Üzerindeki Yorumlar”, Sanat Tarihi Yıllığı, S.12, İstanbul, 1983, s.21-34.

Eyice, Semavi, “XVIII. Yüzyılda Türk Sanatı ve Türk Mimarisinde Avrupa Neo Klasik Üslubu”, Sanat Tarihi Yıllığı, S.9-10, İstanbul, 1981, s. 163-190.

Gültekin, R. Eser, "Türklerde Bereket Sembolü Olarak Kullanılan Meyve Motifleri ve Mimaride Değerlendirilmesi”, Turkish Studies, C.3, S.5, Ankara, 2008, s.9-31.

Gündoğdu, Hamza, “İkonografik Açıdan Türk Sanatında Rûmî ve Palmetler”, Sanat Tarihinde İkonografik Araştırmalar, Ankara, 1993, s. 199-201.

Haseki, Metin, Plastik Açıdan Türk Mezar Taşları, Devlet Güzel Sanatlar Akademisi Yayınları, İstanbul, 1984. İşli, H. Necdet, Osmanlı Serpuşları, İstanbul, Avrupa Kültür Başkenti, Ebru Maatbacılık, İstanbul, 2009.

Kalfazade, Selda - Ertuğrul, Özkan, "Kandil ve Kandilin Motif Olarak Anadolu Türk Sanatındaki Kullanımı Üzerine”, Sanat Tarihi Araştırmaları Dergisi, C.2, S.5, İstanbul, 1989, s. 23-34.

Karamağaralı, Beyhan, Ahlat Mezartaşları, Kültür Bakanlığı Yayınları, Ankara, 1992.

Karkmaz, Esat, Eski Türk İnançları ve Şamanizm Terimleri Sözlüğü, Anahtar Kitaplar Yayınları, İstanbul, 2003.

Kırzıoğlu, M. Fahrettin, “Khazarlar'ın Kazak ve Borçalı Boylarından Oluşan Karapapaklar'da İnsan Heykelli Kabirtaşları Yapma Geleneği”, İslam Dünyasında Mezarlıklar ve Defin Gelenekleri, C.1, Ankara, 1996, s. 285-298.

Kurtişoğlu, Gülay Apa, "Sadelikten Gösterişe Edirne Osmanlı Dönemi Mezar Taşları", Trakya Üniversitesi Edebiyat Fakültesi Dergisi, C.8, S. 16, Edirne, 2018, s. 32-56.

Kuru, Alev Çakmakoğlu, "Orta Asya Türk Sanatında Palmet ve Lale Motiflerinin Değerlendirilmesi Hakkında Bir Deneme", Belleten, C.61, 1997, s. 4-37.

Kutlu, Hüseyin, Kaybolan Medeniyetimiz Hekimoğlu Ali Paşa Camii Haziresi'ndeki Tarihi Mezar Taşları, Biksad Yayınevi, İstanbul, 2005.

Laqueur, Hans Peter, "Osmanlı Mezar Taşlarının Süslemesinde Bitkisel Motifler", Suud Kemal Yetkin'e Armağan, Hacettepe Üniversitesi Armağan Dizisi:1, Ankara, 1984, s. 263-273. 
Laqueur, Hans Peter, Hüve'l-Bâki İstanbul'da Osmanlı Mezarlıkları ve Mezar Taşları, (Çev.: Selahattin Dilidüzgün), İstanbul, 1997.

Ögel, Bahaeddin, Türk Kültür Tarihine Giriş, C. 2, Türk Tarih Kurumu Yayınları, Ankara, 2000.

Sözen, Metin - Tanyeli, Uğur, Sanat Kavramları ve Terimleri Sözlüğü, Remzi Kitabevi, İstanbul, 2005.

Tali, Şerife, "Kayseri/Gesi Mezarlığı Mezar Taşları Üzerine Bir Deneme”, Atatürk Üniversitesi Türkiyat Araştırmaları Enstitüsü Dergisi, S.49, Erzurum, 2013, s. 359-390.

Tuncel, Gül, “Üsküp Alaca Camii Haziresindeki Şahideler”, Hacettepe Üniversitesi Edebiyat Fakültesi Dergisi, C.22, S.1, Ankara, 2005, s.215-236.

Tüfekçioğlu, Abdulhamit, "Türk- İslam Dönemi Türbe ve Mezar Taşı Kitabelerinde Tarih İbareleri", Geçmişten

Günümüze Mezarlık Kültürü ve İnsan Hayatına Etkileri Sempozyumu, İstanbul, 1999, s.394-404.

Uzunçarşıll, İ. Hakkı, Osmanlı Devleti'nin Kuruluşundan İstanbul'un Fethine Kadar, C.1, Türk Tarih Kurumu Yayınları, İstanbul, 2015, s.507-518.

Yakıt, İsmail, "Vefat Tarihlerinde Ebced ve Anlam Sanatı", Geçmişten Günümüze Mezarlık Kültürü ve İnsan Hayatına Etkileri Sempozyumu, İstanbul, 1999, s.405-417.

Yariş, Sahure, Üsküdar'daki Bir Grup Cami ve Hazirelerindeki Mezar Taşları, Atatürk Üniversitesi Sosyal Bilimler Enstitüsü Sanat Tarihi Anabilim Dalı, (Yayınlanmamış Doktora Tezi), Erzurum, 2015.

Yeşil, Yılmaz, "Muskanın Tarihsel ve İşlevsel Açıdan Değerlendirilmesi ve Bu Bağlamda Zeyneddin Baba Örneklemi”, Türk Bilig, S.30, 2015, s. 49-58. 


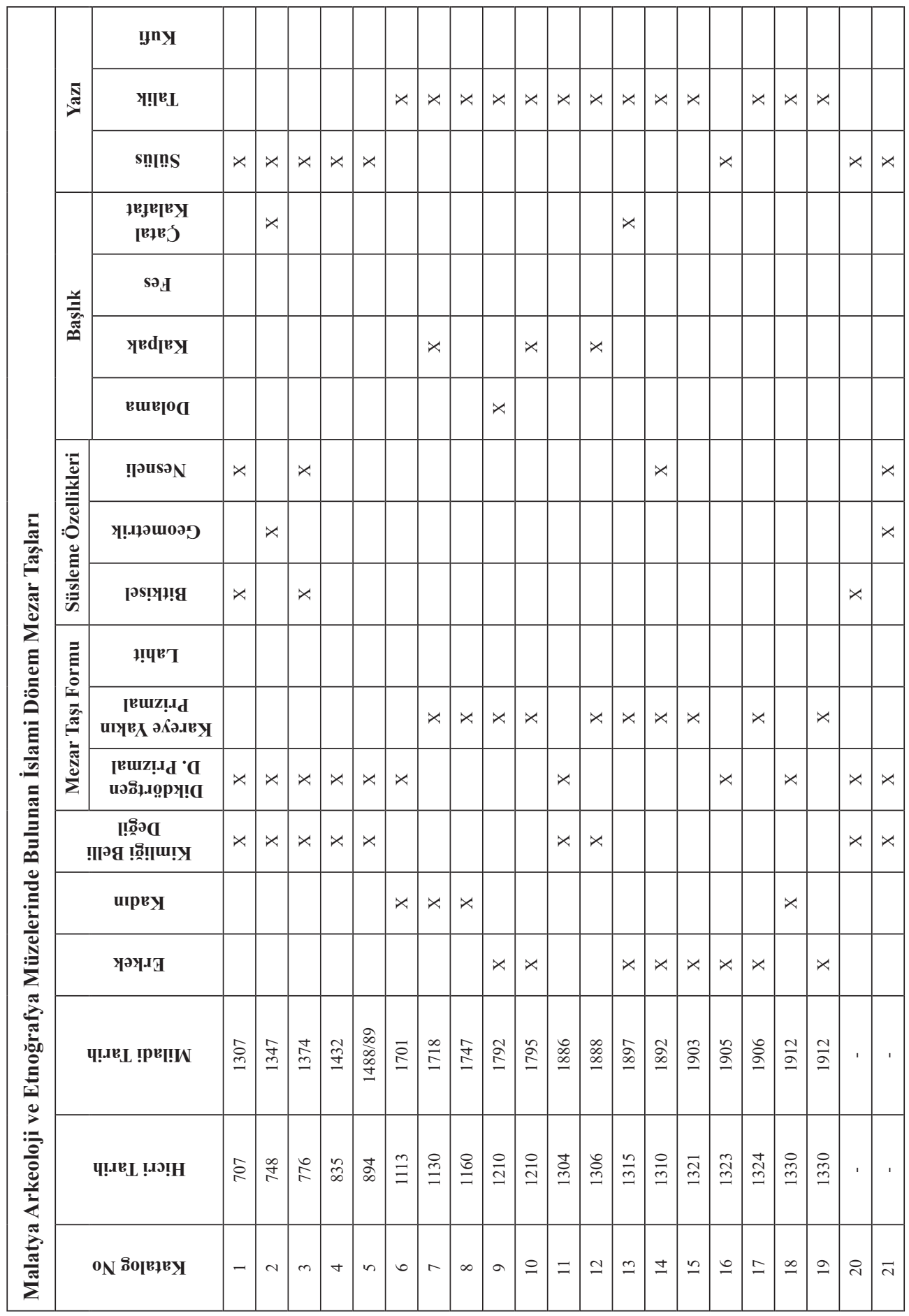




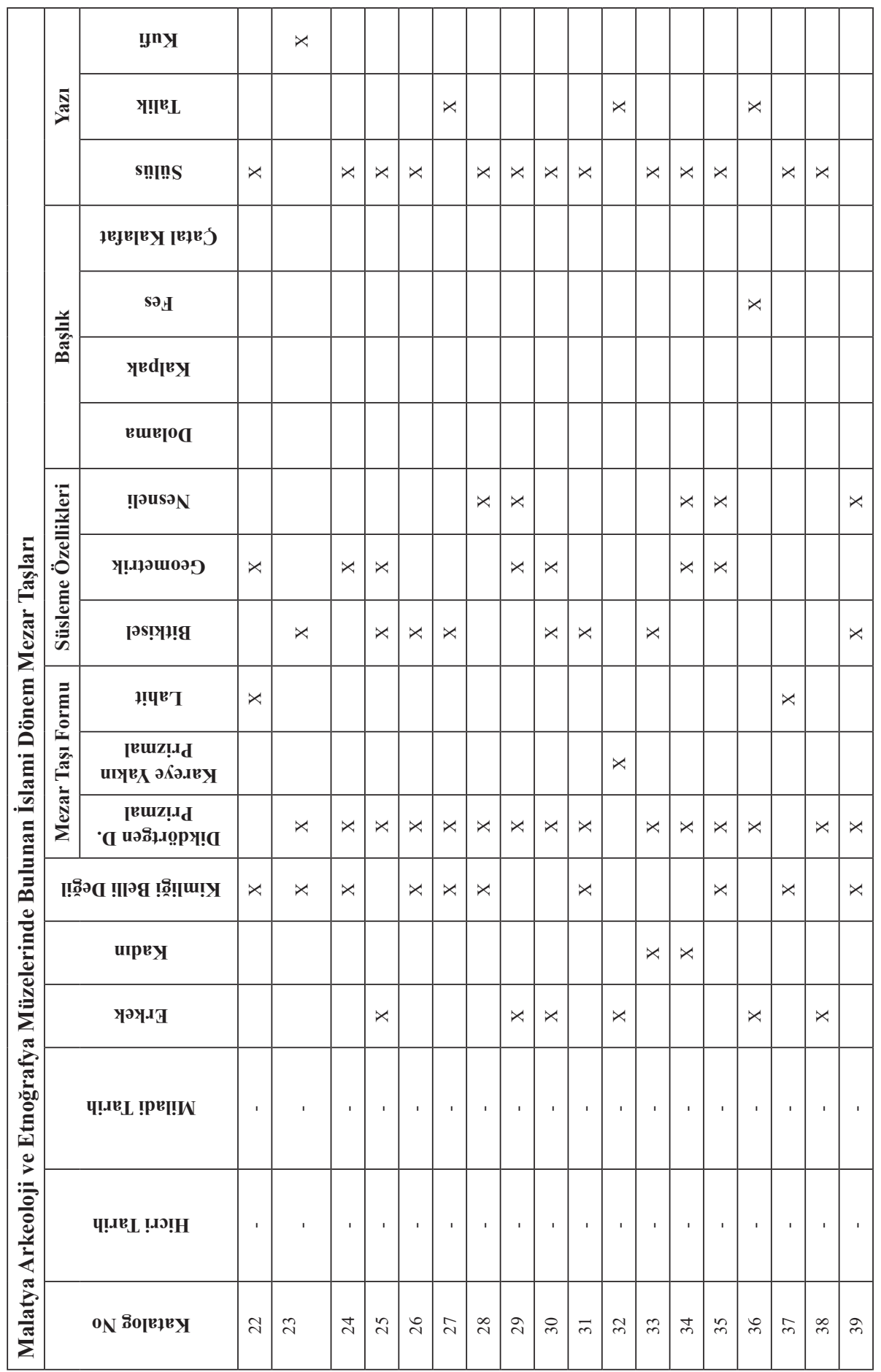


